\title{
Use of acid whey protein concentrate as an ingredient in nonfat cup set-style yogurt
}

\author{
Bryan Wherry, ${ }^{1}$ David M. Barbano, ${ }^{2 *}$ and Mary Anne Drake ${ }^{1}$ \\ ${ }^{1}$ Southeast Dairy Foods Research Center, North Carolina State University, Raleigh 27695 \\ ${ }^{2}$ Northeast Dairy Foods Research Center, Department of Food Science, Cornell University, Ithaca, NY 14853
}

\begin{abstract}
Acid whey resulting from the production of soft cheeses is a disposal problem for the dairy industry. Few uses have been found for acid whey because of its high ash content, low $\mathrm{pH}$, and high organic acid content. The objective of this study was to explore the potential of recovery of whey protein from cottage cheese acid whey for use in yogurt. Cottage cheese acid whey and Cheddar cheese whey were produced from standard cottage cheese and Cheddar cheese-making procedures, respectively. The whey was separated and pasteurized by high temperature, short time pasteurization and stored at $4^{\circ} \mathrm{C}$. Food-grade ammonium hydroxide was used to neutralize the acid whey to a $\mathrm{pH}$ of 6.4 . The whey was heated to $50^{\circ} \mathrm{C}$ and concentrated using ultrafiltration and diafiltration with 11 polyethersulfone cartridge membrane filters (10,000-kDa cutoff) to $25 \%$ total solids and $80 \%$ protein. Skim milk was concentrated to $6 \%$ total protein. Nonfat, unflavored set-style yogurts $(6.0$ $\pm 0.1 \%$ protein, $15 \pm 1.0 \%$ solids) were made from skim milk with added acid whey protein concentrate, skim milk with added sweet whey protein concentrate, or skim milk concentrate. Yogurt mixes were standardized to lactose and fat of $6.50 \%$ and $0.10 \%$, respectively. Yogurt was fermented at $43^{\circ} \mathrm{C}$ to $\mathrm{pH} 4.6$ and stored at $4^{\circ} \mathrm{C}$. The experiment was replicated in triplicate. Titratable acidity, $\mathrm{pH}$, whey separation, color, and gel strength were measured weekly in yogurts through 8 wk. Trained panel profiling was conducted on $0,14,28$, and 56 d. Fat-free yogurts produced with added neutralized fresh liquid acid whey protein concentrate had flavor attributes similar those with added fresh liquid sweet whey protein but had lower gel strength attributes, which translated to differences in trained panel texture attributes and lower consumer liking scores for fat-free yogurt made with added acid whey protein in-
\end{abstract}

Received January 3, 2019.

Accepted May 10, 2019.

*Corresponding author: dmb37@cornell.edu gredient. Difference in $\mathrm{pH}$ was the main contributor to texture differences, as higher $\mathrm{pH}$ in acid whey protein yogurts changed gel structure formation and waterholding capacity of the yogurt gel. In a second part of the study, the yogurt mix was reformulated to address texture differences. The reformulated yogurt mix at $2 \%$ milkfat and using a lower level of sweet and acid whey ingredient performed at parity with control yogurts in consumer sensory trials. Fresh liquid acid whey protein concentrates from cottage cheese manufacture can be used as a liquid protein ingredient source for manufacture of yogurt in the same factory.

Key words: acid whey, sweet whey, yogurt

\section{INTRODUCTION}

Whey protein is collected following the coagulation or precipitation of casein during cheese manufacture. Most whey protein recovery and whey protein products are made from sweet whey from production of cheeses made by rennet coagulation. After removal from cheese vats, liquid whey is centrifuged to reduce fat content and pasteurized to prevent further lactic acid production by starter organisms. Whey protein can be concentrated using UF (Modler et al., 1983; de Wit, 1998) and dried to produce whey protein concentrate (WPC; protein content $30-90 \%$ ) or whey protein isolate (protein content >90\%; Lopes et al., 2006).

Whey protein concentrates and isolates are used in a wide variety of food applications. Whey protein supplementation in foods includes flavored bars, infant formula, and various other foods to increase protein content (Onwulata et al., 2001). Enriching foods with protein using WPC or whey protein isolate has become a popular trend in food manufacturing because of the economic, physical, and nutritional benefits (Tunick, 2009). Added whey protein in the form of WPC and whey protein isolate ingredients has improved waterbinding (Kontopidis et al., 2002, 2004), foaming (Bals and Kulozik, 2003), gelling (Kersten et al., 2005), and emulsifying (Leman et al., 2005) properties in food systems. 
Due to increased cheese production, dairy products such as ice cream, yogurt, and flavored beverages have used WPC as a replacement for nonfat dry milk (NDM; Morr and Ha, 1993). Decisions to use or not use whey protein products as an ingredient are based on both ingredient cost and the value of the functionality delivered by the whey protein ingredient. Whey protein can be an effective fat replacer when added to ice cream (Yilsay et al., 2006). Whey proteins have been added to protein beverages for increased nutrient density (Wagoner et al., 2015). Whey protein powders have been added to milk for yogurt manufacture to increase TS and protein concentration, which increases firmness and viscosity and reduces syneresis (Lucey et al., 1999; Lopes et al., 2006). In the United States, yogurt production increased from 19.97 million $\mathrm{kg}$ in 1960 to 2.1 billion $\mathrm{kg}$ in 2013, with an annual per capita consumption of $6.7 \mathrm{~kg}$ (IDFA, 2017). The yogurt market in the United States was worth $\$ 3.9$ billion in 2010 and continues to grow. Blended and set-style yogurts are the main sellers, contributing up to $40 \%$ of yogurt; Greek style yogurt makes up 30\% of sales, and specialty yogurts and kids' yogurts make up the majority of the rest of yogurt sales (Kilara and Chandan, 2013). Whey protein concentrate is a cost-effective and functionally sound ingredient as an alternative to NDM in yogurt formulations (Sodini et al., 2005).

Most whey protein powders come from sweet whey from rennet-set cheeses such as Cheddar or mozzarella (Smithers, 2015). Another type of whey stream is acid whey, which comes from the production of soft cheeses ( $\mathrm{pH} \sim 4.5$ ) and is a disposal issue for the dairy industry. In 2015, about 181.6 million $\mathrm{kg}$ of cottage cheese curd was produced in the United States, which resulted in acid whey disposal of more than 8.17 million $\mathrm{kg}$ of whey protein annually (USDA, 2015). Due to its high biological oxygen demand and chemical oxygen demand, acid whey can have negative effects on the environment and ecosystems where it may be disposed (Prazeres et al., 2012).

The low $\mathrm{pH}$, high lactic acid concentration, and high calcium phosphate content of acid whey makes it difficult to use as an ingredient in foods. Drying acid whey is troublesome due to its high lactic acid content. Lactic acid causes lumping and caking of particles during spray drying (Dec and Chojnowski, 2006). There are 2 main sources of acid whey in the United States: Greek yogurt and that which comes from acid-coagulated cheeses, such as cottage cheese. Acid whey from Greek yogurt contains little or no available true protein compared with acid whey from production of soft cheese, such as cottage cheese (Barrantes and Morr, 1997; Smithers, 2015). Some larger producers of Greek yogurt have invested in methods of transforming Greek acid whey into a useable substance such as lactose or biofuel or the application of nanofiltration to demineralize the acid whey and separate it into lactose and lactic acid (Chandrapala et al., 2015; Erickson, 2017). In contrast, the protein from cottage cheese acid whey is underused as a possible protein source. The goal of this investigation was to evaluate the potential of acid whey protein (AWP) from cottage cheese as a whey protein source for addition to yogurt in substitution for sweet whey protein (SWP). Using neutralization and filtration technology, our study demonstrates a potential use for liquid WPC from cottage cheese acid whey directly as a fresh liquid ingredient in other dairy products produced at the same factory, thus eliminating the need for evaporation and drying of the acid whey product.

\section{MATERIALS AND METHODS}

\section{Experimental Overview}

Acid whey protein concentrate, SWP concentrate, and skim milk concentrate (SMC) were used to manufacture $6.0 \%$ protein nonfat yogurts. All whey proteins and UF skim milk were manufactured at the North Carolina State University dairy research pilot plant (Raleigh, NC). Fat-free yogurts were manufactured from skim milk and from each protein source. Fat-free yogurt was selected for the study because fat-free yogurt would allow the most sensitivity for detection of flavor and texture differences caused by use of different milk protein sources. The entire experiment was repeated 3 times. The purpose of this portion of the study was to determine whether whey protein recovered from cottage cheese acid whey could be used as an ingredient in liquid concentrate form to produce acceptable yogurt in the same factory. If successful, then a follow-up consumer evaluation of product using AWP recovered from cottage cheese whey to produce cup set yogurt would be conducted.

Acid Whey Production. Cottage cheese was made using approximately $800 \mathrm{~kg}$ of skim milk $(0.2 \%$ fat, $3.3 \%$ protein) obtained from the North Carolina State University Research and Education System (Raleigh, NC). Skim milk was HTST pasteurized at $72^{\circ} \mathrm{C}$ for 15 s (model T4 RGS-16/2, SPX Flow Technology, Greensboro, $\mathrm{NC}$ ), cooled to $31^{\circ} \mathrm{C}$, and transferred to a $1,500-\mathrm{L}$ cheese vat (model TH0041, Kusel Equipment, Watertown, WI). The warm pasteurized milk was inoculated with R-604 cheese culture (frozen, $0.22 \mathrm{~g} / \mathrm{kg}$ of milk) containing Lactococcus lactis ssp. lactis biovar diacetylactis (Chr. Hansen, Milwaukee, WI) and allowed to ferment to a $\mathrm{pH}$ of 4.6 at $31^{\circ} \mathrm{C}$ for about $7 \mathrm{~h}$. No rennet was used to make the cottage cheese. Once fermentation was complete, the curd was cut with 1 -cm cheese knives 
and allowed to heal for $10 \mathrm{~min}$. The curd was then stirred and the temperature was increased gradually to $57^{\circ} \mathrm{C}$ over a period of $30 \mathrm{~min}$. Once the curd was fully cooked, the whey was drained and the unseparated acid whey was HTST pasteurized $\left(72^{\circ} \mathrm{C}\right.$ for $\left.15 \mathrm{~s}\right)$, separated using an inline hot bowl centrifugal separator (model J5-OSCP-1, JSC PLAVA, Savery USA, Orlando, FL) at $50^{\circ} \mathrm{C}$, cooled to $4^{\circ} \mathrm{C}$, weighed, and placed in a jacketed tank for overnight storage at $4^{\circ} \mathrm{C}$. Approximately $450 \mathrm{~kg}$ of pasteurized separated cottage cheese whey was produced from each batch.

The next day, the cooled acid whey was neutralized and the protein was concentrated by UF. Acid whey $\mathrm{pH}$ was measured at $4^{\circ} \mathrm{C}$ using a $\mathrm{pH}$ meter (Orion model 0290, Thermo Scientific, Waltham, MA) and probe (VWR model 89231-572, VWR Analytical, Radnor, PA) calibrated at $4^{\circ} \mathrm{C}$ and continuously monitored throughout the neutralization process. Ammonium hydroxide (food grade-USP, 30\% wt/vol; VWR Analytical) was used to neutralize the acid whey. The ammonium hydroxide was pumped into the $4^{\circ} \mathrm{C}$ whey using a peristaltic pump in $20-\mathrm{mL}$ doses. The entire whey system was continuously stirred throughout the neutralization process. This process ensured that the ammonium hydroxide was quickly dispersed to minimize localized areas of high $\mathrm{pH}$ and protein denaturation. Ammonium hydroxide was added at 1-min intervals and $\mathrm{pH}$ was measured $30 \mathrm{~s}$ after each addition. Neutralization was continued until the $\mathrm{pH}$ of the whey reached $6.4\left(\sim 800 \mathrm{~mL}\right.$ of $\left.30 \% \mathrm{NH}_{4} \mathrm{OH}\right)$. Temperature was monitored throughout the neutralization process. Titratable acidity (TA) measurements were taken before and after neutralization. Addition of $\mathrm{NH}_{4} \mathrm{OH}$ had no detectable effect on temperature of the batch of whey (data not shown). Titratable acidity changed from $0.55 \%$ (before neutralization) to $0.27 \%$ (after neutralization; data not shown). Temperature of the whey was increased to $50^{\circ} \mathrm{C}$ after neutralization and before UF. The $\mathrm{pH}$ of the neutralized whey at $50^{\circ} \mathrm{C}$ was confirmed with a $\mathrm{pH}$ probe and meter calibrated to appropriate reference $\mathrm{pH}$ for $50^{\circ} \mathrm{C}$. Once the temperature was increased to $50^{\circ} \mathrm{C}, \mathrm{pH}$ was measured and was 5.89 .

The neutralized whey was ultrafiltered using a pilotscale UF unit (model lab 46, Filtration Engineering, Champlin, MN). Two spiral-wound UF membranes were used (Synder Filtration, Vacaville, CA; nominal cutoff $=10,000$ Da; total surface area $=13.4 \mathrm{~m}^{2}$ ). The temperature for UF was $50^{\circ} \mathrm{C}$. Deionized water was added as $40 \%$ (wt/wt) of the original weight of whey for diafiltration. The run time was approximately 2.5 h. A Lactoscope FTIR (model FTA, Delta Instruments, Drachten, the Netherlands) was used to measure protein, fat, and lactose every $15 \mathrm{~min}$ to control the process of production of the WPC. The UF permeate produced by UF of neutralized acid whey was not processed fur- ther; this is an area that needs further work if the UF permeate was not processed by waste treatment.

Sweet Whey Production. Cheddar cheese was manufactured using approximately $200 \mathrm{~kg}$ of raw whole milk (3.7\% fat, $3.0 \%$ protein) that was obtained from the North Carolina State University Research and Education System. Milk was HTST pasteurized at $72^{\circ} \mathrm{C}$ for $15 \mathrm{~s}$ (model T4 RGS-16/2, SPX Flow Technology, Greensboro, NC), cooled to $31^{\circ} \mathrm{C}$, and transferred to a 1,500-L cheese vat (model TH0041, Kusel Equipment). The warm pasteurized milk was inoculated with R-604 cheese culture (frozen, $0.22 \mathrm{~g} / \mathrm{kg}$ of milk) containing Lactococcus lactis ssp. lactis biovar diacetylactis (Chr. Hansen) and allowed to ripen for $60 \mathrm{~min}$ at $31^{\circ} \mathrm{C}$. Next, the milk was coagulated with double-strength recombinant rennet (DCI Star Coagulant, Dairy Connection Inc., Madison, WI) for $30 \mathrm{~min}$ at a rate of $0.09 \mathrm{~mL} /$ $\mathrm{kg}$ of milk diluted 80 -fold in deionized water. The curd was cut with 1-cm cheese knives and allowed to heal for $10 \mathrm{~min}$. The curd was then stirred and the temperature was increased gradually to $39^{\circ} \mathrm{C}$ over a period of $30 \mathrm{~min}$. Once the curd was fully cooked, the unseparated whey was drained and HTST pasteurized $\left(72^{\circ} \mathrm{C}\right.$ for $\left.15 \mathrm{~s}\right)$, separated using an inline hot bowl centrifugal separator (model J5-OSCP-1, JSC PLAVA, Savery USA) at $50^{\circ} \mathrm{C}$, weighed, and placed in a 300-L tank. Approximately $150 \mathrm{~kg}$ of pasteurized separated Cheddar cheese whey at $50^{\circ} \mathrm{C}$ was collected.

The whey (starting $\mathrm{pH}$ 6.34) was ultrafiltered using a pilot-scale UF unit (model lab 46, Filtration Engineering). Two spiral-wound UF membranes were used (Synder Filtration; nominal cutoff $=10,000 \mathrm{Da}$; total surface area $=13.4 \mathrm{~m}^{2}$ ). The temperature for UF was $50^{\circ} \mathrm{C}$. Diafiltration water was added as $40 \%$ of the original weight of whey. The run time was approximately 2.5 h. A Lactoscope FTIR (Delta Instruments) was used to measure protein, fat, and lactose every $15 \mathrm{~min}$ for process control.

$S M C$. Approximately $70 \mathrm{~kg}$ of raw skim milk $(0.2 \%$ fat, $3.3 \%$ true protein, $4^{\circ} \mathrm{C}$ ) was obtained from the North Carolina State University Research and Education System. Raw skim milk was subjected to UF at $4^{\circ} \mathrm{C}$ to concentrate the protein to $6.0 \%$. Before UF, the membrane cartridges were cleaned with a $0.1 \mathrm{~N}$ sodium hydroxide solution (VWR Analytical) followed by rinsing with deionized water. After the rinse step, each batch of raw skim milk was concentrated using an UF system (model Pellicon 2, Millipore Inc., Billerica, MA) with 11 cartridges of polyethersulfone membrane filters (model P2B010V05, Millipore Inc.; nominal separation cutoff $=10,000 \mathrm{Da}$; surface area $=0.5 \mathrm{~m}^{2}$ ). The pump used to circulate the product was a variable-speed peristaltic pump (model 77410-10, Cole Parmer, Vernon Hills, IL) equipped with model 77601-00 pump heads 
with silicone tubing (model 96440-73, Cole Parmer). The pump was run at $100 \%$ speed capacity to maximize cross-flow velocity across the surface of the membranes to minimize membrane fouling. A Lactoscope FTIR (Delta Instruments) was used to measure protein, fat, and lactose every $15 \mathrm{~min}$. Final protein, fat, lactose, and solids of the skim milk UF concentrate were $6.13 \%$ (wt/wt), $0.15 \%$ (wt/wt), $4.41 \%$ (wt/wt), and $12.4 \%$ (wt/wt), respectively.

\section{Formulation of Fat-Free Yogurt Mixes}

The AWP yogurt mixes comprised approximately $87.0 \%$ skim milk (0.10\% fat, $3.28 \%$ true protein), $4.88 \%$ NDM (95.0\% TS, 35.0\% CP; Milk Specialties, Eden Prairie, MN), and $7.75 \%$ neutralized liquid acid WPC ingredient to yield a yogurt mix with approximately $6.50 \%$ lactose, $6.00 \%$ true protein, $0.20 \%$ total fat, and $14.8 \%$ TS. (All percentages throughout this paper are wt/wt.) The SMC yogurt mixes comprised approximately $10 \%$ skim milk, $88.0 \%$ SMC ingredient, $<0.10 \%$ NDM, and 2.00\% lactose (5120 refined lactose, Hilmar, Hilmar, CA) to yield a yogurt mix with approximately $6.50 \%$ lactose, $6.00 \%$ true protein, $0.20 \%$ total fat, and $14.0 \%$ TS. The SWP yogurt mixes comprised approximately $87.0 \%$ skim milk, $8.30 \%$ sweet liquid SWP concentrate ingredient, and $5.00 \% \mathrm{NDM}$ to yield a yogurt mix with approximately $6.50 \%$ lactose, $6.00 \%$ true protein, $0.20 \%$ total fat, and $14.5 \%$ TS. Formulations for each type of yogurt mix were calculated before the processing day using the analysis data from a Lactoscope FTIR (Delta Instruments) for true protein, fat, and lactose concentrations to make a $28-\mathrm{kg}$ batch of yogurt mix for thermal processing.

Yogurt Production. Yogurt production was replicated 3 times from different batches of ingredients. Yogurt mixes were preheated to $60^{\circ} \mathrm{C}$, homogenized at $20.7 \mathrm{MPa}$ (17.2 $\mathrm{MPa}$ first stage, $3.5 \mathrm{MPa}$ second stage), and then heated to $88^{\circ} \mathrm{C}$ and held for $7 \mathrm{~min}$ using an EHVH thermal processor (Microthermics, Raleigh, NC). Approximately $22 \mathrm{~kg}$ of yogurt mix was inoculated with $0.03 \%$ (wt/wt) Yo-Fast 20 yogurt culture (Chr. Hansen), mixed for 2 min, poured into sanitized [soaked in $0.5 \%$ ( $\mathrm{vol} / \mathrm{vol}$ ) sanitizer solution for $30 \mathrm{~s}$ (XY-12, Ecolab, St. Paul, MN)] containers (177 $\mathrm{mL}$; Choice-Pac, San Francisco, CA), and placed in an incubator at $43^{\circ} \mathrm{C}$. The $\mathrm{pH}$ was monitored every half hour until a $\mathrm{pH}$ of 4.8 was reached, then was measured every 10 min until $\mathrm{pH} 4.65$ (about $5.5 \mathrm{~h}$ ). Yogurt was then placed in a cooler at $4^{\circ} \mathrm{C}$ to cool. Yogurts were cooled to $<10^{\circ} \mathrm{C}$ within $8 \mathrm{~h}$.

Color. Hunter L and a and CIE b* values were measured on the raw and pasteurized-homogenized mixes using an Ultra Scan Pro spectrophotometer (Hunter
Associates Laboratory Inc., Reston, VA), with L being luminosity (the degree of lightness from dark to light), a being the degree of redness or greenness, and $b^{*}$ being the degree of yellowness or blueness (Quiñones et al., 1997; Cheng et al., 2018). Hunter values were computed from the reflectance data in the range of 360 to 750 $\mathrm{nm}$ at 5 -nm intervals, Illuminant $\mathrm{A}$ with a $10^{\circ}$ observer angle. Measurements were taken on liquid mixes tempered to $4^{\circ} \mathrm{C}$.

\section{Chemical and Physical Testing}

Yogurts were evaluated starting on d 1, with d 0 being the day the yogurt was produced. Each yogurt was tested on the same day each week for 8 wk. Each test was performed in triplicate.

$p H$ Determination and TA. The $\mathrm{pH}$ was determined by calibrated $\mathrm{pH}$ meter measurements (Orion model 0290, Thermo Scientific) and probe (VWR model 89231-572, VWR Analytical) at $4^{\circ} \mathrm{C}$. Each week the $\mathrm{pH}$ meter was calibrated in the cooler at $4^{\circ} \mathrm{C}$ with buffers 4.0 and 7.0 with the buffer manufacturers' temperature correction applied (VWR Analytical), and yogurt $\mathrm{pH}$ was measured at $4^{\circ} \mathrm{C}$. Titratable acidity was measured using the standard methods for examination of dairy products (Hooi et al., 2004a; method 15.021).

Mojonnier. Fat content of pasteurized-homogenized yogurt mixes was measured using the Mojonnier method (Hooi et al., 2004b; method 15.086) with modifications. Yogurt mixes were measured in triplicate. Ether collection beakers were predried and weighed before measurement. Yogurt mixes were warmed to $40^{\circ} \mathrm{C}$ in a water bath before sampling. Ten grams of yogurt mix was measured into preweighed Mojonnier flasks and recorded. Ammonium hydroxide $(1.5 \mathrm{~mL} ; 30 \% \mathrm{wt} / \mathrm{wt}$; VWR Analytical) was added to the flask and mixed. Three drops of phenolphthalein indicator (Sigma-Aldrich, St. Louis, MO) were added. The first extraction included $10 \mathrm{~mL}$ of ethanol, $25 \mathrm{~mL}$ of ethyl ether, and 25 $\mathrm{mL}$ of petroleum ether (all from Sigma-Aldrich). The flask was mixed by shaking and centrifuged for $30 \mathrm{~s}$ at $8 \times g$ at $23^{\circ} \mathrm{C}$ to separate the phases. The ether layer was removed and added to a preweighed and dried 250$\mathrm{mL}$ beaker. A second extraction was carried out using $5 \mathrm{~mL}$ of ethanol, $15 \mathrm{~mL}$ of ethyl ether, and $15 \mathrm{~mL}$ of petroleum ether. The flask was mixed by shaking and centrifuged for $30 \mathrm{~s}$ at $8 \times g$ at $23^{\circ} \mathrm{C}$. Again, the ether layer was removed and added to the $250-\mathrm{mL}$ beaker. A third extraction was performed using $15 \mathrm{~mL}$ of ethyl ether and $15 \mathrm{~mL}$ of petroleum ether. The flask was mixed by shaking and centrifuged for $30 \mathrm{~s}$ at $8 \times g$ at $23^{\circ} \mathrm{C}$. The solvent was removed by evaporation in a fume hood, and then each beaker plus fat residue was placed in a forced-air oven at $100^{\circ} \mathrm{C}$ for about $30 \mathrm{~min}$. 
Once drying was complete, the beaker was removed and placed in a desiccator to cool. After cooling, the beaker was weighed to the nearest $0.1 \mathrm{mg}$. The fat content was calculated as follows:

$$
\begin{gathered}
\text { fat }(\%)=[(\text { mass of beaker and extract } \\
- \text { mass of empty beaker }- \text { mass of blank }) / \\
\text { mass of test sample }] \times 100 \% .
\end{gathered}
$$

Kjeldahl Protein and TS. The total nitrogen (method 990.20; AOAC International, 2016) and nonprotein nitrogen (method 990.21; AOAC International, 2016) of each yogurt mix and the ingredients used for yogurt mix production were measured using the Kjeldahl method. The casein content of both yogurt mixes and the ingredients used for yogurt mix manufacture were measured using the noncasein nitrogen (NCN) method (method 998.05; AOAC International, 2016). True protein was calculated as total nitrogen $-\mathrm{NPN} \times$ 6.38 , casein was calculated as total nitrogen $-\mathrm{NCN} \times$ 6.38 , and serum protein content was calculated as NCN $-\mathrm{NPN} \times 6.38$. The concentration of whey protein contributed by AWP WPC 80 or SWP WPC 80 in the yogurt mix was calculated using the weight of the AWP WPC 80 or SWP WPC 80 and the measured casein and whey protein concentration in those ingredients to calculate the whey protein contribution to the yogurt mix from AWP or SWP WPC 80. Total solids were analyzed by the direct forced-air method (method 990.20; AOAC International, 2016) and fat was analyzed by ether extraction (method 989.05; AOAC International, 2016).

Syneresis. Syneresis (whey separation) was measured using a modified method from Lucey et al. (1998). Lucey et al. (1998) evaluated 3 methods of measuring syneresis: volumetric flask, Petri dish, and low-speed centrifugation. They found that the amount of whey separation was very dependent on the geometry of the container used for the test, with the container that had more surface area of the gel exposed (i.e., Petri dish) giving the highest amount of syneresis. Therefore, in our study we decided to use a typical yogurt cup container for the syneresis testing because it had a surface area:volume ratio that would reflect the conditions under which yogurt would be stored. At each time point, 3 cups of each yogurt treatment were examined for syneresis. Cups were weighed to the nearest milligram. Any visible liquid on top of the yogurt was suctioned off with a pipette, and the cup was reweighed. The initial weight minus the final weight represented the weight of the free whey. Whey separation was expressed as percentage of total yogurt weight.
Gel Strength. Gel strength was measured at $4^{\circ} \mathrm{C}$ using a modified method from Schmidt et al. (2000), Pang et al. (2016), and Houzé et al. (2005). Samples were tested in cups that were $6.5 \mathrm{~cm}$ tall and $2.5 \mathrm{~cm}$ in diameter. Gel strength attributes were measured using an Instron 5542 rheometer (Instron, Norwood, MA) equipped with a 1.27 -cm-diameter spherical stainless steel probe (TA-18, Texture Technologies, Hamilton, MA). The limits of texture parameters were set up using a $0.7-\mathrm{kg}$ load cell with $0.8 \mathrm{~mm} / \mathrm{s}$ pretest crosshead speed, $1.0 \mathrm{~mm} / \mathrm{s}$ test speed with a penetration depth of $1 \mathrm{~cm}, 1.0 \mathrm{~mm} / \mathrm{s}$ posttest speed, and a $0.001 \mathrm{~N}$ trigger force. Measurements of firmness, compression, adhesion, and cohesion were analyzed using BlueHill 2.0 software (Instron). Firmness was measured as the maximum force of compression (newtons) observed under the measurement conditions (dmax) during the penetration of the probe into the product. Compression was measured as the area under the curve for compression. Adhesion was measured as the maximum force of retraction. Cohesion was measured by the area under the curve for the retraction.

\section{Trained Panel Sensory Testing}

All sensory testing was performed in compliance with the North Carolina State University Institutional Review Board for Human Subjects. The yogurts were dispensed into 3-digit coded soufflé cups (Solo Cup, Highland Park, IL), lidded, and tempered to $15^{\circ} \mathrm{C}$. Aromatics and basic taste intensities were evaluated in duplicate by trained panelists $(\mathrm{n}=8)$ using an established sensory language for yogurts (Desai et al., 2013) and a 0- to 15-point universal Spectrum intensity scale on $0,14,28$, and 56 d. Panelists were between the ages of 23 and $55 \mathrm{yr}$, and each had more than 150 $\mathrm{h}$ of experience with descriptive analysis of yogurts. Panelists expectorated samples and were provided with room-temperature deionized water for palate cleansing. Texture attributes were evaluated in separate sessions on individual coded cups of yogurt to evaluate yogurt before and after stirring (Desai et al., 2013). Conditions for texture evaluation were similar to those described for flavor. For all sensory evaluations, each panelist evaluated each yogurt in duplicate. Data were collected using Compusense Cloud (Compusense Inc., Guelph, ON, Canada).

\section{Consumer Sensory Testing}

A consumer acceptance test was conducted after 14 d of storage on replicate 3 following analysis of trained panel and instrumental measurements to ensure con- 
sistency of replicate 3 with the other 2 replicates. Yogurts were mixed with a strawberry fruit base at 20\% (Fruit Gel, Fruit Crown, Farmingdale, NY; wt/ wt). Consumers $(\mathrm{n}=100)$ were self-reported yogurt consumers. Yogurts were dispensed into lidded $60-\mathrm{mL}$ soufflé cups labeled with random 3-digit codes. Consumers evaluated samples monadically in a randomized balanced block design, and data were collected using Compusense Cloud. A 120-s rest was enforced between samples, during which panelists were instructed to clean their palates with deionized water and unsalted crackers. Consumers answered questions about overall liking, sweetness, texture, thickness, and aftertaste. Liking was scored on a 9 -point hedonic scale ( $1=$ dislike extremely and $9=$ like extremely). Aftertaste liking was scored only when aftertaste was indicated.

\section{Data Analysis}

All analyses were performed at $95 \%$ confidence $(P$ $<$ 0.05). Statistical analyses were conducted with XLSTAT version 2017.19.5 (Addinsoft, Paris, France) and SAS (version 9.4, SAS Institute Inc., Cary, NC). An ANOVA (model: protein source, replicate, protein source $\times$ time, and protein source $\times$ time $\times$ time, with time as a continuous variable) was performed on the analytical data (pH, gel strength, syneresis, color, and TA). For trained panel sensory data, the same ANOVA was performed with panelist and panelist interactions included in the model, with means separation performed using least squares means (SAS, SAS Institute Inc.). Time data were transformed to avoid colinearity effects on statistical analysis (Glantz and Slinker, 2001). Proximate analysis and consumer hedonic scores were evaluated using 1-way ANOVA with Fisher's least significant difference for means separation.

\section{RESULTS AND DISCUSSION}

\section{Protein Source Composition}

There was no difference in the whey protein content of liquid WPC 80 made from acid or Cheddar whey $(P>0.05$; Table 1$)$. There was a difference in true protein and fat content of liquid WPC 80 made from acid and Cheddar whey $(P<0.05$; Table 1$)$. Although the starting milk for cottage cheese-making contained a low level of fat, that fat is retained in the cottage cheese curd, and the acid whey before UF contained little if any fat. The Cheddar whey before separation contained about 0.2 to $0.3 \%$ fat, and most of that was removed with a cream separator before UF. However, about $0.04 \%$ fat remains in the separated whey before UF, and that fat will be concentrated by the UF pro-
Table 1. Composition of liquid acid whey protein (AWP) concentrate and sweet whey protein (SWP) concentrate

\begin{tabular}{lcc}
\hline Item & $\begin{array}{c}\text { Neutralized } \\
\text { AWP concentrate }\end{array}$ & $\begin{array}{c}\text { SWP } \\
\text { concentrate }\end{array}$ \\
\hline Fat $(\mathrm{g} / 100 \mathrm{~g})$ & $0.24^{\mathrm{b}}$ & $1.03^{\mathrm{a}}$ \\
TS $(\mathrm{g} / 100 \mathrm{~g})$ & $27.1^{\mathrm{a}}$ & $22.0^{\mathrm{b}}$ \\
True protein $(\mathrm{g} / 100 \mathrm{~g})$ & $19.5^{\mathrm{a}}$ & $17.6^{\mathrm{b}}$ \\
Casein $(\mathrm{g} / 100 \mathrm{~g})$ & $2.99^{\mathrm{a}}$ & $0.70^{\mathrm{b}}$ \\
Whey protein $(\mathrm{g} / 100 \mathrm{~g})$ & $16.5^{\mathrm{a}}$ & $16.9^{\mathrm{a}}$ \\
Protein on dry basis $(\%)$ & $72^{\mathrm{b}}$ & $80^{\mathrm{a}}$ \\
Ammonia $(\mathrm{mg} / 100 \mathrm{~g})$ & $17.0^{\mathrm{a}}$ & $1.46^{\mathrm{b}}$ \\
\hline
\end{tabular}

$\overline{\mathrm{a}, \mathrm{b}}$ Means within a row with different superscripts differ $(P<0.05)$.

cess, resulting in the higher fat concentration in the UF retentate from Cheddar versus acid whey. This was not a concern because the final fat content of yogurts was standardized. Another difference between the 2 ingredients was the ammonia content. Concentrated acid whey had higher $(P<0.05)$ ammonia $(17.0 \mathrm{mg} / 100 \mathrm{~g})$ than concentrated Cheddar whey (1.46 mg/100 g). Again, this result was expected due to the use of ammonium hydroxide to neutralize the acid whey.

\section{Yogurt Composition}

Composition of yogurt mixes was determined after pasteurization and before culturing. No difference between AWP and SWP yogurt mixes in TS $(P>0.05)$ was detected; however, SMC yogurt mix had lower TS $(P<0.05 ;$ Table 2$)$. The TS concentration was lower for the SMC yogurt mix because lactose was removed from the milk by UF, so the lactose as a percentage of the other milk solids was lower in this treatment. No difference in true protein concentrations between AWP and SWP yogurt mixes was detected $(P>0.05)$, whereas SMC yogurt mix had lower true protein $(P<$ $0.05)$. However, all values were within ranges that were targeted. No difference in whey protein concentrations in AWP and SWP yogurt mixes was detected $(P>$ 0.05). The lower whey protein in SMC yogurt mix $(P$ $<0.05)$ was expected because no added whey protein ingredient was used in the SMC yogurt mix formulation. Conversely, casein protein was higher in the SMC yogurt mix compared with the AWP and SWP yogurt mixes $(P<0.05)$, which was due to UF skim milk being the base ingredient. The contribution of whey protein to the mix was higher for SWP yogurt mix $(P<0.05)$ than for AWP yogurt mix (Table 2).

\section{Fermentation and $\mathrm{pH}$}

The mean initial pH of the AWP- and SWP-fortified yogurt mixes (Figure 1$)$ was lower $(P<0.05 ; 6.49$ and 6.52 , respectively) than that of the SMC protein source 
(6.65). All yogurt mixes were cultured under the same conditions. The fermentation time to reach a finished $\mathrm{pH}$ of 4.7 was longer for AWP (390 min) than for SWP or SMC (300 min; Figure 1). There was a strong linear and moderate quadratic effect of time of fermentation on mix $\mathrm{pH}$ and an interaction $(P<0.05)$ effect of protein source with both the linear and quadratic terms for fermentation time, with the linear effect being the strongest (Figure 1). The interaction effect of protein source with time of fermentation indicates that the rate of change with time was different $(P<0.05)$ among the different protein sources. In future work, the level of residual ammonia might be controlled by additional diafiltration of the neutralized acid whey to bring the residual ammonia level closer to that of sweet WPC. The higher resistance to $\mathrm{pH}$ decrease by AWP-fortified mix could also have been caused by a higher residual calcium phosphate in the AWP-fortified mix, but the diafiltration step in processing should have removed soluble calcium from the acid whey. No difference in the starting TA (Table 3) of the 3 mixes was detected $(P>0.05)$, so we do not think that higher residual calcium phosphate in the AWP-fortified mix was the cause of higher resistance to $\mathrm{pH}$ decrease.

After overnight storage for cooling, there was a slight increase in the $\mathrm{pH}$ of AWP yogurts (from 4.7 to 4.77), whereas the other 2 treatments were at $\mathrm{pH} 4.53$ at time zero (Figure 2), a difference of $0.24 \mathrm{pH}$ units at $4^{\circ} \mathrm{C}$. Thus, the hydrogen ion concentration was not as high in the AWP yogurt as in the SWP and SMP yogurts after cooling but was the same as the other treatments before cooling. Something must have taken up hydrogen ions in the AWP treatment as a result of cooling due to the effect of cooling the yogurt (to $4^{\circ} \mathrm{C}$ ) on dissociation of acids and bases and interactions with minerals.

During the 8 wk of storage at $4^{\circ} \mathrm{C}$, the $\mathrm{pH}$ of SMC, AWP, and SWP yogurts decreased on average by 0.26 , 0.21 , and 0.25 , respectively, and at all time points AWP yogurt had a higher $\mathrm{pH}$ than SMC and SWP $(P<$ 0.05 ; Figure 2). Yogurt $\mathrm{pH}$ was affected by both time of storage and protein source $(P<0.05$; Table 3$)$. For interactions between $\mathrm{pH}$ and time, all protein sources had quadratic relationships. The similar change in $\mathrm{pH}$ in all 3 treatments with time of storage at $4^{\circ} \mathrm{C}$ probably reflects the slow production of a similar amount of additional lactic acid, which increased hydrogen ion concentration to the same extent in all 3 treatments.

\section{$T A$}

The TA of the yogurt mixes before fermentation was $0.4,0.43$, and 0.42 for SMC, AWP, and SWP mixes, respectively. The TA was affected by time $(P<0.05)$, but no effect of protein source $(P>0.05)$ was detected (Figure 2; Table 3). During the 8 wk of storage at $4^{\circ} \mathrm{C}$, the TA of SMC, AWP, and SWP yogurts increased on average by $0.23,0.25$, and $0.25 \%$, respectively. There was a strong quadratic and moderate linear effect of storage time on TA. There was no interaction (linear or quadratic) of protein source with time on TA, indicating that no difference in the rate of acid production with storage time was detected $(P>0.05)$.

\section{Syneresis}

Syneresis was affected by both time and protein source $(P<0.05$; Table 3$)$. The AWP yogurt $(2.90 \%)$ had higher syneresis than the SMC $(0.30 \%)$ or SWP $(0.40 \%)$ yogurts at all time points during shelf life $(P<$ 0.05 ; Figure 3$)$. The AWP yogurt increased in syneresis over 8 wk of storage at $4^{\circ} \mathrm{C}(P<0.05)$, whereas no significant change of syneresis with time was detected for SMC and SWP yogurts $(P>0.05)$. There was a strong quadratic and moderate linear effect of time of storage on syneresis and an interaction effect of protein source with time for both the linear and quadratic terms, with

Table 2. Composition of original nonfat and reformulated $2 \%$ fat yogurts ${ }^{1}(\mathrm{~g} / 100 \mathrm{~g}$ of product)

\begin{tabular}{|c|c|c|c|c|c|c|}
\hline \multirow[b]{2}{*}{ Item } & \multicolumn{3}{|c|}{ Original } & \multicolumn{3}{|c|}{ Reformulated } \\
\hline & $\mathrm{SMC}$ & AWP & SWP & $\mathrm{SMCr}$ & AWPr & SWPr \\
\hline Fat & $0.16^{\mathrm{b}}$ & $0.17^{\mathrm{b}}$ & $0.21^{\mathrm{b}}$ & $1.98^{\mathrm{a}}$ & $2.00^{\mathrm{a}}$ & $1.99^{\mathrm{a}}$ \\
\hline TS & $13.9^{\mathrm{d}}$ & $14.7^{\mathrm{c}}$ & $14.5^{\mathrm{c}}$ & $15.6^{\mathrm{bc}}$ & $18.4^{\mathrm{a}}$ & $17.5^{\mathrm{b}}$ \\
\hline True protein & $5.91^{\mathrm{a}}$ & $6.04^{\mathrm{a}}$ & $6.00^{\mathrm{a}}$ & $4.91^{\mathrm{b}}$ & $5.00^{\mathrm{b}}$ & $4.90^{\mathrm{b}}$ \\
\hline Casein & $4.76^{\mathrm{a}}$ & $3.79^{\mathrm{b}}$ & $3.65^{\mathrm{bc}}$ & $3.90^{\mathrm{b}}$ & $3.52^{\mathrm{c}}$ & $3.49^{\mathrm{c}}$ \\
\hline Whey protein & $1.15^{\mathrm{b}}$ & $2.25^{\mathrm{a}}$ & $2.35^{\mathrm{a}}$ & $0.98^{\mathrm{c}}$ & $1.28^{\mathrm{b}}$ & $1.30^{\mathrm{b}}$ \\
\hline Whey protein from $\mathrm{WPC}^{2}$ & $\mathrm{NA}^{3}$ & $1.28^{\mathrm{b}}$ & $1.46^{\mathrm{a}}$ & NA & $0.41^{\mathrm{c}}$ & $0.42^{\mathrm{c}}$ \\
\hline
\end{tabular}

${ }^{\mathrm{a}-\mathrm{d}}$ Means within a row with different superscripts differ $(P<0.05)$.

${ }^{1} \mathrm{SMC}=$ skim milk concentrate yogurt mix; AWP $=$ acid whey protein yogurt mix; SWP $=$ sweet whey protein yogurt mix; SMCr = reformulated SMC; AWPr = reformulated AWP; SWPr $=$ reformulated SWP.

${ }^{2}$ Whey protein concentrate (WPC) contributed by whey protein was calculated based the Kjeldahl total nitrogen, nonprotein nitrogen, and noncasein nitrogen in the AWP and SWP WPC 80 ingredient.

${ }^{3}$ Not applicable. 
the quadratic term being the strongest. The interaction effect of protein source with storage time indicates that the change during storage time was different for the different protein sources $(P<0.05)$; this can be seen clearly in Figure 3.

\section{Gel Strength}

Gel strength attributes (firmness, compression, adhesion, and cohesion) were affected by both protein source and time of storage $(P<0.05$; Table 3$)$. All gel strength attributes, for all protein sources, increased with time $(P<0.05 ;$ Figures 4 and 5$)$. The AWP yogurt had lower $(P<0.05)$ firmness and compression than the SMC yogurt (Table 3), whereas no difference between AWP and SWP yogurts was detected $(P>0.05)$. There was a quadratic and linear effect $(P<0.05)$ of storage time on both firmness and compression, with values increasing with time of storage (Table 3; Figure 4), and an interaction effect of protein source with storage time on firmness and compression, with values increasing less with time for AWP than for SWP and SMC. The AWP yogurt had lower $(P<0.05)$ adhesion and cohesion than the SMC yogurt (Table 3), whereas no difference in adhesion and cohesion between AWP and SWP yogurts was detected $(P>0.05)$.

Yogurt instrumental and sensory texture properties were affected by pH. Martin et al. (1999) and Martens (1972) reported that yogurts at $\mathrm{pH} 4.2$ to 4.4 had higher thickness than yogurts at $\mathrm{pH} 4.7$ to 4.8 . Rönnegård and Dejmek (1993) observed higher viscosities in yogurts as pH decreased from 4.5 to 4.25 . The AWP yogurts had higher $\mathrm{pH}$ values than the SMC and SWP yogurts at all time points and never reached below a $\mathrm{pH}$ of 4.52. Increase of gel strength in yogurts could be explained by the effect of lower $\mathrm{pH}$ on the electrical

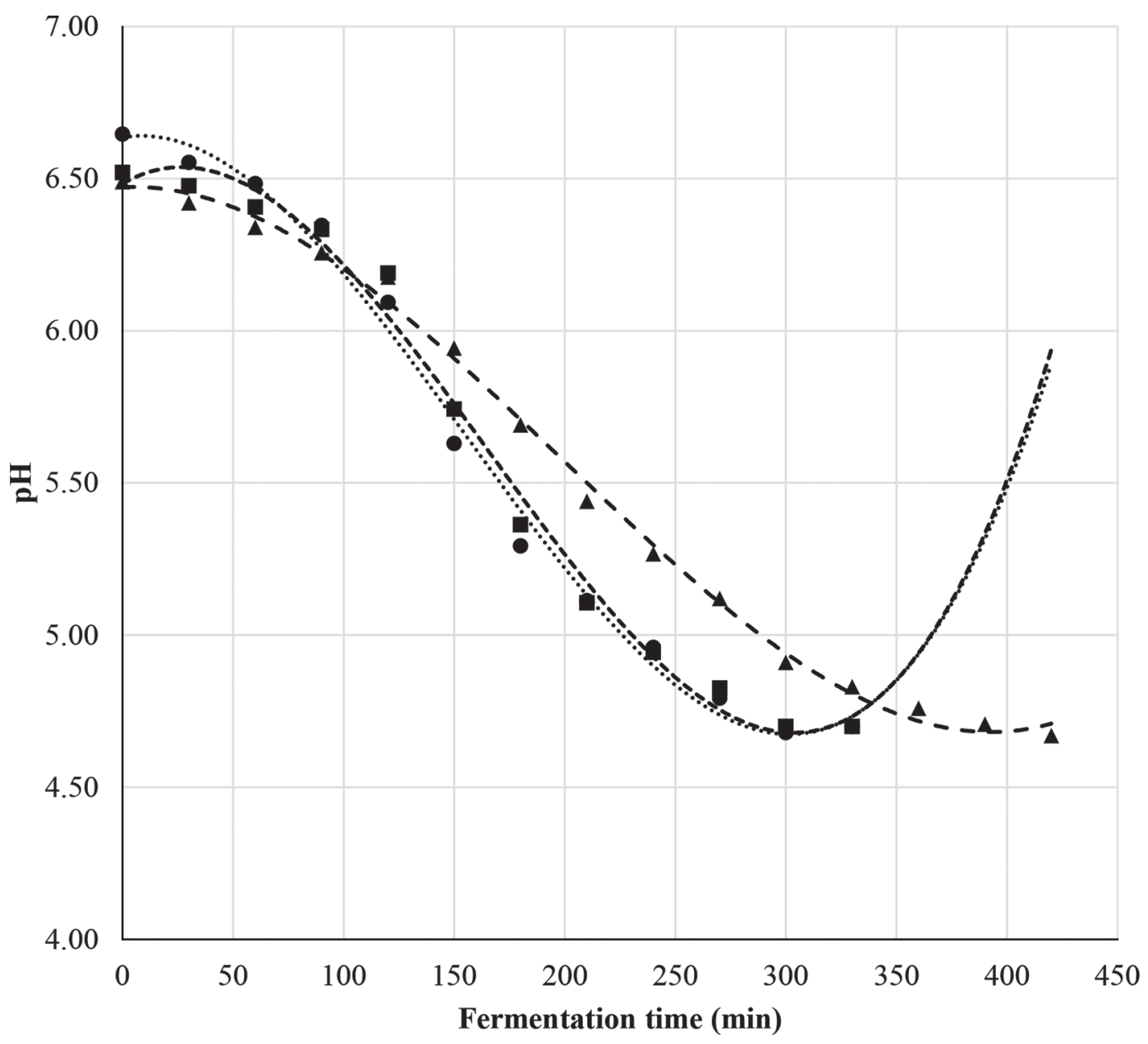

Figure 1. Time course of $\mathrm{pH}$ change during fermentation of skim milk concentrate yogurt $(\bullet)$ and third-degree polynomial regression line (dotted line), acid whey protein yogurt $(\boldsymbol{\Lambda})$ and third-degree polynomial regression line (long-dashed line), and sweet whey protein yogurt $(\boldsymbol{\square})$ and third-degree polynomial regression line (short-dashed line). Nonfat yogurts were inoculated with $0.03 \%$ (wt/wt) yogurt culture and incubated at $43^{\circ} \mathrm{C}$. 
Table 3. Least squares means instrumental $\mathrm{pH}$, titratable acidity (TA), and texture metrics of fat-free yogurt using 3 protein sources ${ }^{1}$ measured at $0,7,14,21,28,42,49$, and $56 \mathrm{~d}$ of $4^{\circ} \mathrm{C}$ storage

\begin{tabular}{|c|c|c|c|c|c|c|c|}
\hline \multirow[b]{2}{*}{ Parameter } & \multicolumn{3}{|c|}{ Protein source } & \multirow[b]{2}{*}{ LSD } & \multicolumn{2}{|c|}{ Time of storage } & \multirow[b]{2}{*}{$\mathrm{R}^{2}$} \\
\hline & $\mathrm{SMC}$ & AWP & SWP & & Linear & Quadratic & \\
\hline $\mathrm{pH}$ & $4.33^{\mathrm{b}}$ & $4.61^{\mathrm{a}}$ & $4.34^{\mathrm{b}}$ & 0.264 & * & * & 0.954 \\
\hline $\mathrm{TA}(\%$ acid $)$ & $1.17^{\mathrm{a}}$ & $1.22^{\mathrm{a}}$ & $1.19^{\mathrm{a}}$ & $\mathrm{NS}^{2}$ & * & * & 0.780 \\
\hline Syneresis (\% wt of white mass) & $0.30^{\mathrm{b}}$ & $2.90^{\mathrm{a}}$ & $0.40^{\mathrm{b}}$ & 0.081 & $*$ & $*$ & 0.895 \\
\hline Firmness $(\mathrm{N})$ & $0.70^{\mathrm{a}}$ & $0.26^{\mathrm{b}}$ & $0.67^{\mathrm{ab}}$ & 0.411 & * & * & 0.979 \\
\hline Compression (mJ) & $4.72^{\mathrm{a}}$ & $1.64^{\mathrm{b}}$ & $4.17^{\mathrm{ab}}$ & 2.77 & $*$ & $*$ & 0.967 \\
\hline Adhesion $(\mathrm{N})$ & $0.11^{\mathrm{a}}$ & $0.03^{\mathrm{b}}$ & $0.08^{\mathrm{ab}}$ & 0.070 & * & * & 0.880 \\
\hline Cohesion (mJ) & $0.36^{\mathrm{a}}$ & $0.11^{\mathrm{b}}$ & $0.30^{\mathrm{ab}}$ & 0.232 & $*$ & $*$ & 0.706 \\
\hline
\end{tabular}

${ }^{a, b}$ Within a row, different superscripts indicate a significant difference among protein source $(P<0.05)$.

${ }^{1} \mathrm{SMC}=$ skim milk concentrate yogurt; AWP = acid whey protein yogurt; SWP $=$ sweet whey protein yogurt. ${ }^{2} \mathrm{NS}=$ the term for protein source in the ANOVA model was not significant $(P>0.05)$; therefore, calculation and use of LSD is not valid.

$* P<0.05$.

charge on casein (Harwalker and Kalab, 1983), which causes a more rigid gel structure. The higher $\mathrm{pH}$ in AWP yogurts led to lower instrumental gel strength and less ideal sensory texture attributes compared with SMC and SWP yogurts. Water-holding capacity is also affected by pH. Aguilera and Kessler (1989) showed

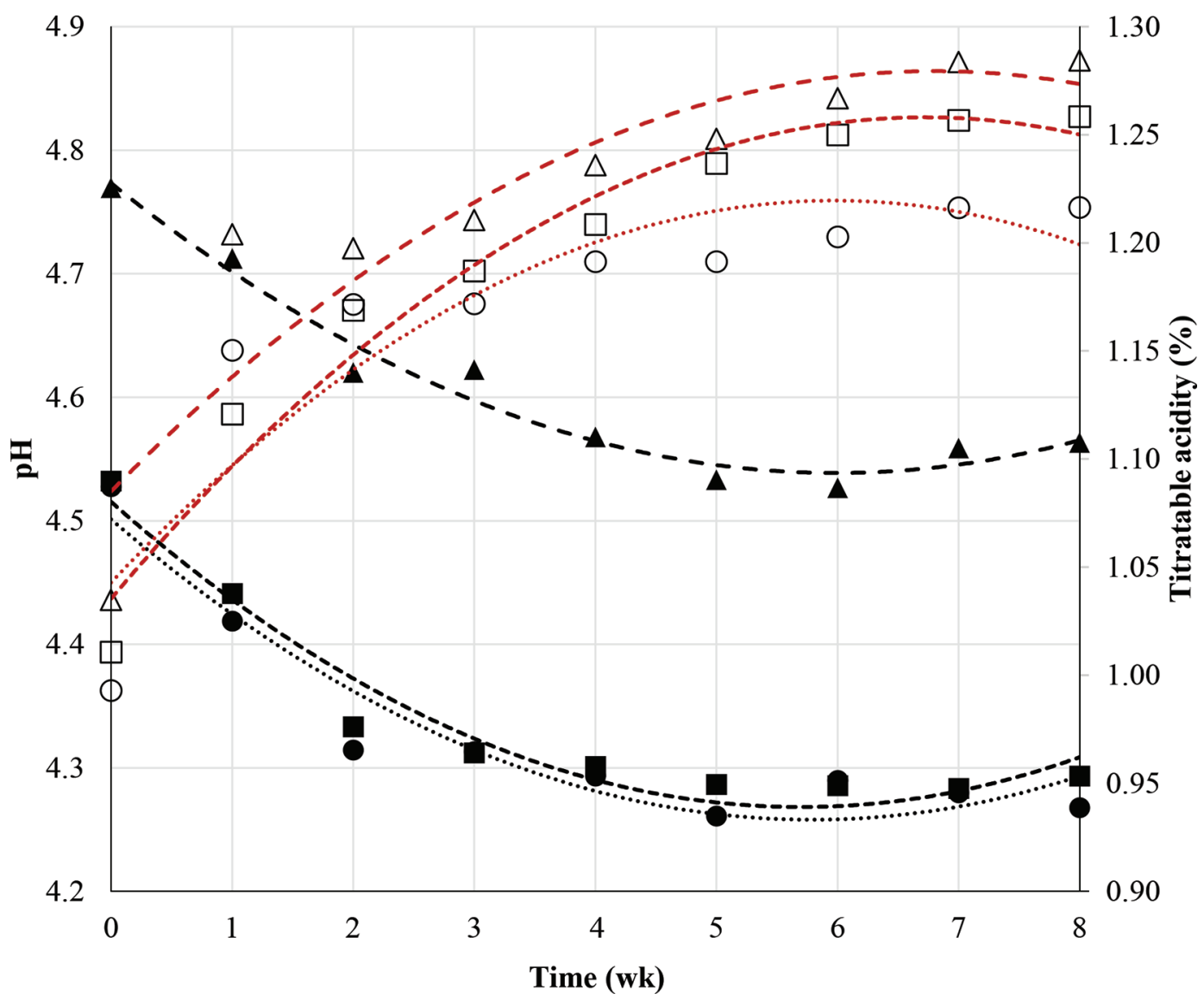

Figure 2. Time course of $\mathrm{pH}$ and titratable acidity after cooling of nonfat yogurts during an 8-wk shelf life. $\mathrm{pH}$ is represented by skim milk concentrate yogurt (SMC; $\bullet$ ) and quadratic regression line (black dotted line), acid whey protein yogurt (AWP; $\mathbf{\Lambda}$ ) and quadratic regression line (black long-dashed line), and sweet whey protein yogurt (SWP; $\mathbf{0})$ and quadratic regression line (black short-dashed line). Titratable acidity is represented by SMC $(O)$ and quadratic regression line (red dotted line), AWP $(\Delta)$ and quadratic regression line (red long-dashed line), and SWP $(\square)$ and quadratic regression line (red short-dashed line). Both properties were measured at $4^{\circ} \mathrm{C}$. 


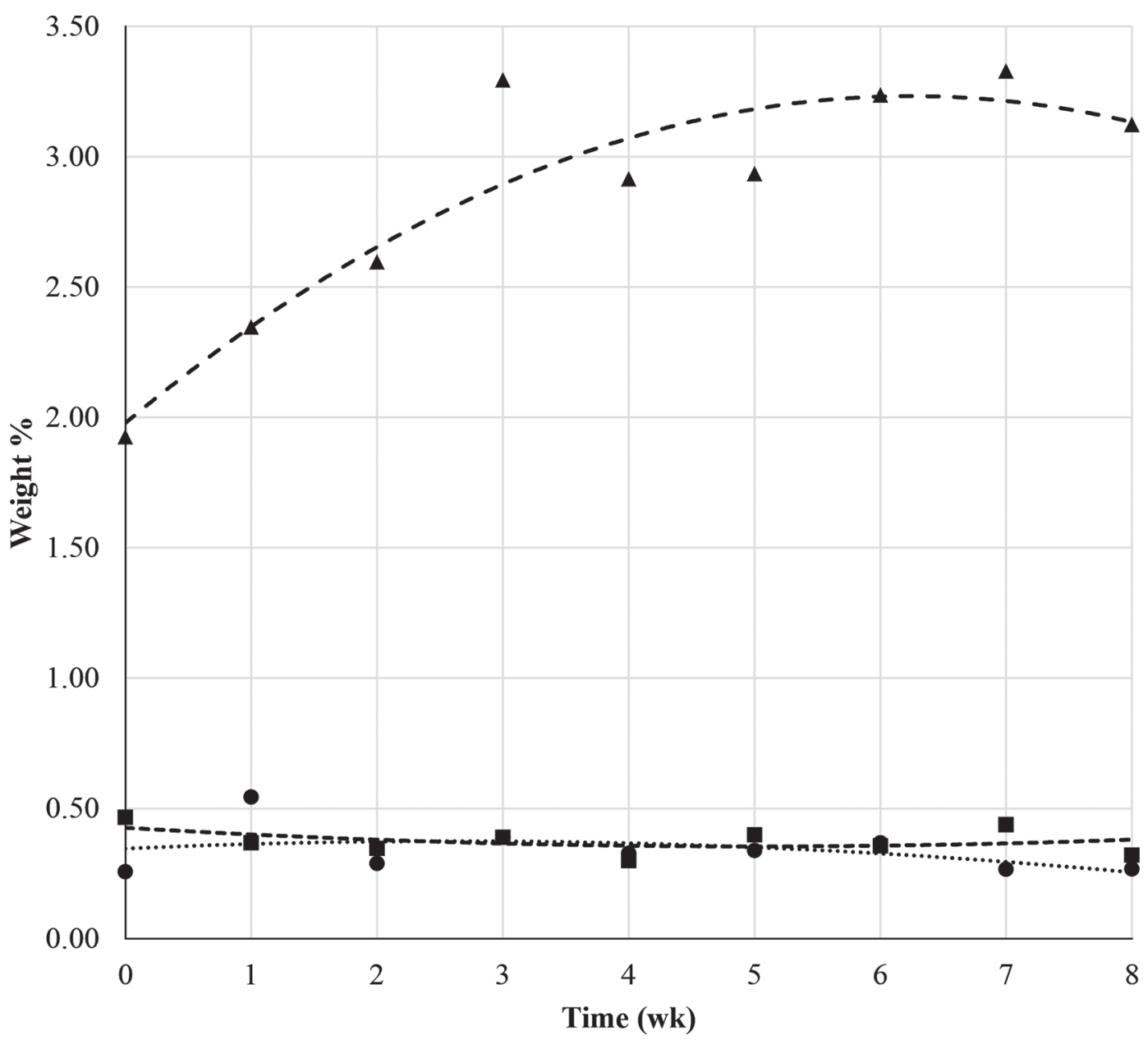

Figure 3. Time course of syneresis amounts expressed in percentage weight for skim milk concentrate yogurt $(\bullet)$, acid whey protein yogurt $(\boldsymbol{\Lambda})$, and sweet whey protein yogurt (ם) over an 8-wk shelf life of nonfat yogurts. Measurements were taken from untested yogurts each week at $4^{\circ} \mathrm{C}$.

that acidified gels had higher water-holding capacity at $\mathrm{pH} 3.7$ than at $\mathrm{pH}$ 5.35. The AWP yogurt had higher values of syneresis than SMC and SWP yogurts at all time points (Figure 3). This is likely due to the $\mathrm{pH}$ difference among the yogurts.

\section{Color Attributes}

Color values of raw and pasteurized-homogenized mixes were measured using Hunter L (whiteness) and a (green-redness) and CIE b* (yellow-blueness) on yogurt mixes at $\mathrm{d} 0$. Both protein source and pasteurizationhomogenization treatment and the interaction of protein source by pasteurization-homogenization treatment had a significant effect on $\mathrm{L}$, a, and $\mathrm{b}^{*}$ values (Table 4). Analysis of variance models for all 3 of the color parameters had $\mathrm{R}^{2}$ values $\geq 0.985$ (Table 4). Yogurt mix made with AWP was more white, less green, and more yellow than yogurt made with skim milk pro- tein. Yogurt mix made with SWP was less white, less green, and more yellow than mix made with AWP. For $\mathrm{L}$ value, pasteurization-homogenization treatment explained $83.5 \%$ of the variation in yogurt mix whiteness, whereas protein source explained only $3.98 \%$ of variation (Table 4$)$. There was a significant effect $(P<0.05)$ of protein source by pasteurization-homogenization treatment interaction on whiteness, which explained $12.1 \%$ of the variation in yogurt mix whiteness. This was in contrast to a and $b^{*}$ values, where the effect of protein source explained $>84 \%$ of the variation in greenness and yellowness.

Color is an influential attribute of appearance and quality. Lightness increase in milk has been reported with pasteurization (Schamberger and Labuza, 2006). This is a result of the denaturation of soluble milk proteins that bind to casein and reflected light. Lightness in yogurt mixes increased after pasteurization compared with raw mixes. Cheng et al. (2018) reported increased 
$b^{*}$ values with increased levels of whey protein as a percentage of total protein in milks. Similar trends were found for a values in milks (Cheng et al., 2018). Our data were consistent with those of Cheng et al. (2018), with increased $b^{*}$ values and a values in AWP and SWP yogurt mixes because of the added whey protein ingredient.

\section{Descriptive Sensory Analysis}

Flavor. No effect $(P>0.05)$ of protein source was detected for the following flavor attributes: aroma intensity, cooked, dairy sour, acetaldehyde flavors, sweet and sour tastes, and astringency (Table 5). For aftertaste intensity, yogurts made with AWP and SWP had higher $(P<0.05)$ scores than SMC yogurt; however, no difference in aftertaste intensity was detected between the 2 whey protein-supplemented yogurts (Table 5). Overall, for all protein sources, aroma intensity, acetaldehyde flavor, sweet taste, and aftertaste intensity had very small changes with time, whereas cooked flavor decreased (from about 3.9 to 3.2; data not shown) with time. Astringency (1.4 to 2.1), dairy sour flavor (1.4 to 1.9), and sour taste (2.1 to 2.7) increased slightly with time of storage (data not shown). No beefy/brothy, cardboard, or soapy flavors or umami taste were detected in the SMC yogurts (Table 5). No difference was detected $(P>0.05)$ in beefy/brothy flavor between AWP and SWP yogurts, while SWP yogurt had higher $(P<0.05)$ cardboard and soapy flavor intensity scores than AWP yogurts (Table 5). The beefy/brothy and cardboard flavors decreased slightly in AWP and SWP yogurts with time of storage. Beefy/brothy flavor has been previously documented in sour creams (Shepard

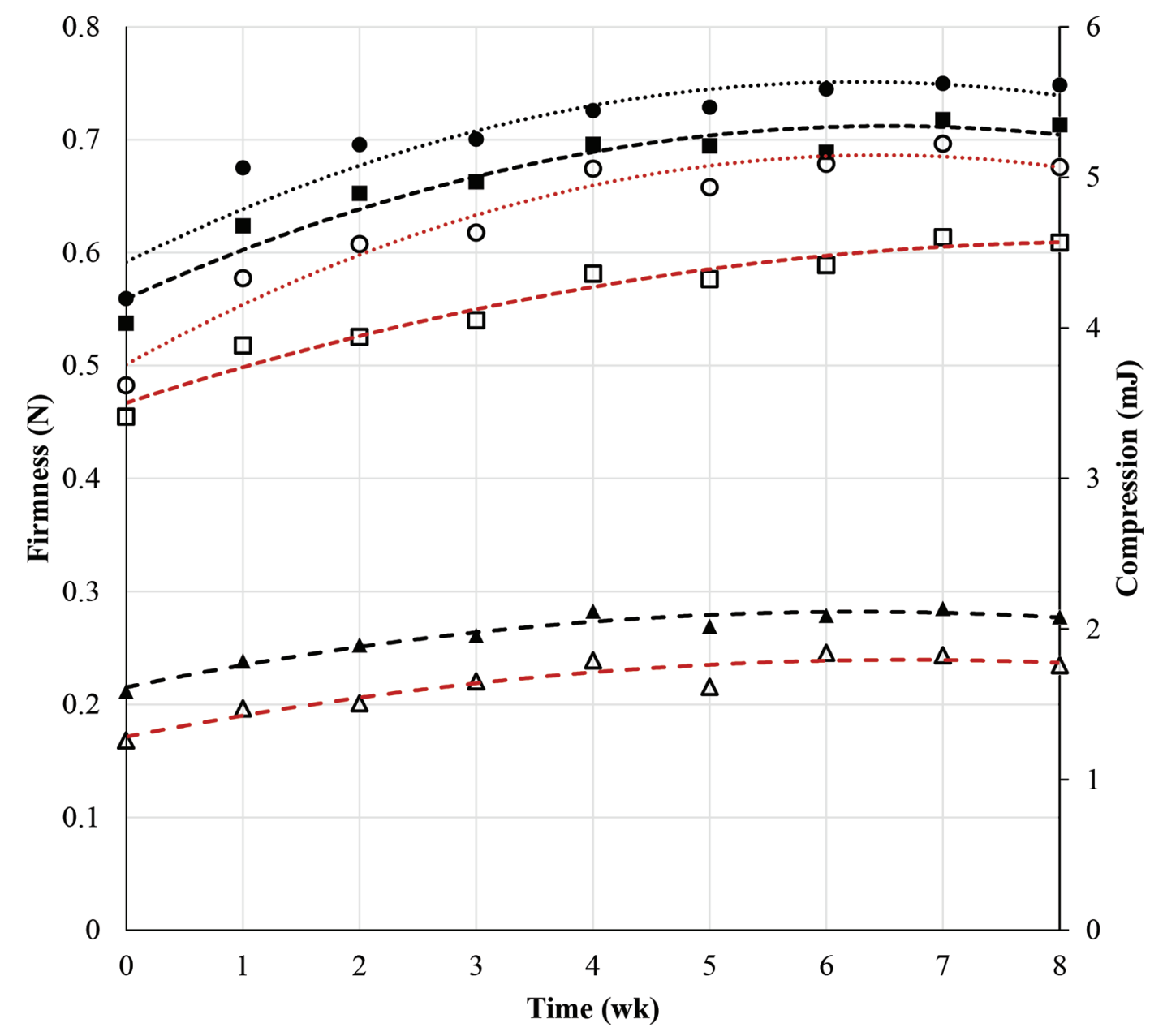

Figure 4. Time course of gel strength attributes for all nonfat yogurts over an 8-wk shelf life. Firmness is represented by skim milk concentrate yogurt (SMC; $)$ and quadratic regression line (black dotted line), acid whey protein yogurt (AWP; $\mathbf{\Delta}$ ) and quadratic regression line (black long-dashed line), and sweet whey protein yogurt (SWP; $\mathbf{\square})$ and quadratic regression line (black short-dashed line). Compression is represented by SMC (O) and quadratic regression line (red dotted line), AWP $(\Delta)$ and quadratic regression line (red long-dashed line), and SWP ( $\square$ ) and quadratic regression line (red short-dashed line). Gel strength attributes were measured at $4^{\circ} \mathrm{C}$. 
et al., 2013) and fortified Greek yogurts (Desai et al., 2013) and has been attributed to high heat treatment or addition of whey protein or both. Cardboard flavor has been documented in whey protein and foods with added whey protein, including Greek yogurt (Carunchia Whetstine et al., 2005; Leksrisompong et al., 2010; Whitson et al., 2010; Desai et al., 2013). Soapy flavor has been documented in nonfat Greek yogurts (Desai et al., 2013) and in whey proteins and whey protein beverages (Carunchia Whetstine et al., 2005; Oltman et al., 2015).

Umami taste was detected only in the AWP-supplemented yogurts (Table 5) and increased slightly with time (data not shown). Soapy flavor did not differ be- tween AWP and SWP yogurts, but there was a slight increase in soapy flavor with time (data not shown). Smith et al. (2016) documented higher intensities of umami taste in acid and cottage cheese whey compared with Cheddar whey. Monosodium glutamate and 5'-nucleotides are recognized as the components that provide umami taste (Reineccius, 2006) as well as organic acids (Rubico and McDaniel, 1992; Drake et al., 2007). Differences in processing conditions among Cheddar and cottage cheese wheys allow bacteria to grow longer in cottage cheese whey as fermentation takes longer for a lower final $\mathrm{pH}$. It is possible that compounds present in AWP concentrate ingredient produced from cottage cheese whey stimulated production of larger amounts

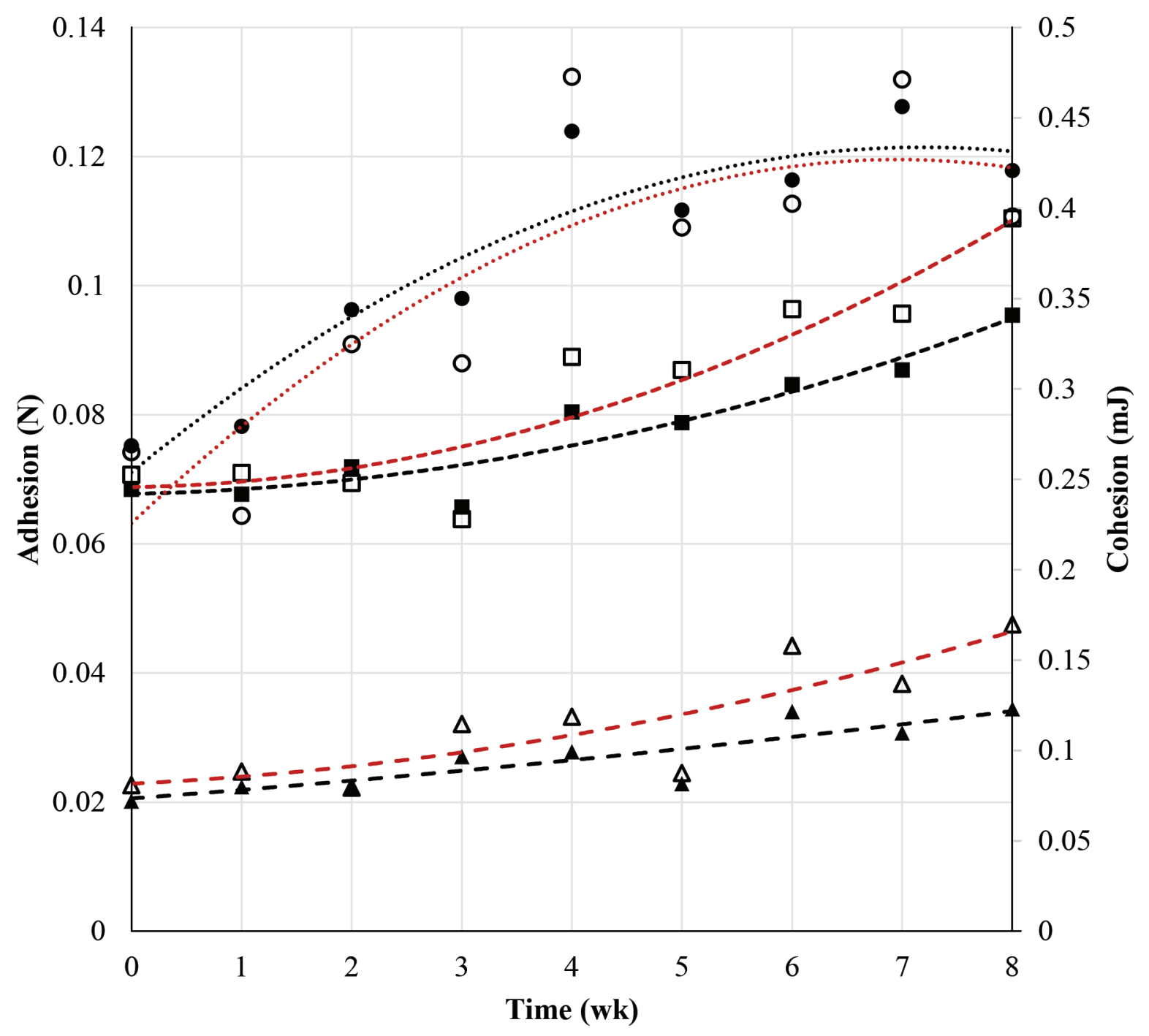

Figure 5. Time-course of gel strength attributes for all nonfat yogurts over an 8-wk shelf life. Adhesion is represented by skim milk concentrate yogurt (SMC; - ) and quadratic regression line (black dotted line), acid whey protein yogurt (AWP; $\mathbf{\Delta}$ ) and quadratic regression line (black long-dashed line), and sweet whey protein yogurt (SWP; $\mathbf{0})$ and quadratic regression line (black short-dashed line). Cohesion is represented by SMC $(\bigcirc)$ and quadratic regression line (red dotted line), AWP $(\Delta)$ and quadratic regression line (red long-dashed line), and SWP ( $\square$ ) and quadratic regression line (red short-dashed line). Gel strength attributes were measured at $4^{\circ} \mathrm{C}$. 
Table 4. Effect of protein source and pasteurization-homogenization treatment on Hunter L (luminosity) and a (red-greenness) values and $\mathrm{CIE}^{*}$ (yellow-blueness) value of raw and pasteurized-homogenized yogurt mixes at $4^{\circ} \mathrm{C}$ made with 3 protein sources

\begin{tabular}{lrrr}
\hline Item & $\mathrm{L}$ & $\mathrm{a}$ & $\mathrm{b}^{*}$ \\
\hline Protein source & & & \\
Acid whey protein & $82.42^{\mathrm{a}}$ & $-1.19^{\mathrm{b}}$ & $7.87^{\mathrm{b}}$ \\
Skim milk protein & $81.62^{\mathrm{b}}$ & $-2.71^{\mathrm{c}}$ & $5.73^{\mathrm{c}}$ \\
Sweet whey protein & $81.76^{\mathrm{b}}$ & $-1.03^{\mathrm{a}}$ & $8.32^{\mathrm{a}}$ \\
Heat treatment & & & \\
Raw & $80.34^{\mathrm{b}}$ & $-1.71^{\mathrm{b}}$ & $6.95^{\mathrm{b}}$ \\
Pasteurized & $83.52^{\mathrm{a}}$ & $-1.57^{\mathrm{a}}$ & $7.66^{\mathrm{a}}$ \\
Model R & 0.995 & 0.985 & 0.989 \\
ANOVA type III & & & \\
Total sum of squares explained & 109.18 & 24.54 & 54.40 \\
Protein source & 4.35 & 20.62 & 46.11 \\
Heat treatment & 91.17 & 0.19 & 4.51 \\
Protein source $\times$ heat treatment & 13.21 & 3.68 & 3.56 \\
Variation explained (\%) & & & \\
Protein source & 3.98 & 84.03 & 84.80 \\
Heat treatment & 83.50 & 0.75 & 8.29 \\
Protein source $\times$ heat treatment & 12.10 & 15.00 & 6.54 \\
\hline
\end{tabular}

${ }^{a-c}$ Protein source, heat treatment, and protein source $\times$ heat treatment interaction were all significant $(P<0.05)$ for $\mathrm{L}, \mathrm{a}$, and $\mathrm{b}^{*}$ values.

of metabolites related to umami flavor produced by starter bacteria growing in the AWP yogurt.

Texture. There was no effect $(P>0.05)$ of protein source detected for the following texture attributes: surface shine, viscosity, denseness, cohesiveness, meltaway, mouth coating, and no stir denseness (Table 6). Surface shine and mouth coating did not change much with time, whereas meltaway increased with time with all protein sources. Viscosity decreased with time for all protein sources. Denseness, cohesiveness, and no stir denseness decreased with time for the AWP yogurts but stayed the same or increased for SWP- and SMCbased yogurts (data not shown). Surface grain, graininess, and jiggle were all higher for AWP yogurt than for SMC yogurt, whereas spoon indent, firmness, no stir firmness, and slurp viscosity were lower for AWP yogurt than for SMC yogurts (Table 6). Surface grain increased with time for the AWP yogurt but did not change for SMC and SWP yogurts, whereas graininess increased with time for all yogurt made with protein sources. Jiggle decreased with time of storage for all protein sources, but the decrease was the largest for SMC yogurt. Spoon indent and slurp viscosity scores changed very little with time, whereas firmness and no stir firmness increased with time for SMC and SWP yogurts but not for AWP yogurts. Ropy and spoon ropy scores were low, and in general all fat-free yogurts in the study had very little ropy character.

\section{Consumer Testing: Fat-Free Yogurts from Replicate 3}

Yogurts with $20 \%$ strawberry fruit base from each treatment from replicate 3 were evaluated by consumers after $14 \mathrm{~d}$ of storage. Fruit base was blended into yogurt by hand on d 14 before consumer testing. A total of 100 self-reported yogurt consumers participated. Males made up $40.0 \%$ of the consumers and females $60.0 \%$. All consumers were between the ages of 18 and $64 \mathrm{yr}$, with the majority being between 18 and $34 \mathrm{yr}$

Table 5. Trained panel flavor profiles of nonfat yogurts evaluated at $1,14,28$, and $56 \mathrm{~d}$ of storage at $4^{\circ} \mathrm{C}^{1}$

\begin{tabular}{|c|c|c|c|c|c|c|}
\hline \multirow[b]{2}{*}{ Flavor attribute } & \multicolumn{3}{|c|}{ Protein source $^{2}$} & \multirow[b]{2}{*}{ LSD } & \multirow{2}{*}{$\begin{array}{l}\text { Time of } \\
\text { storage }\end{array}$} & \multirow[b]{2}{*}{$\mathrm{R}^{2}$} \\
\hline & $\mathrm{SMC}$ & AWP & SWP & & & \\
\hline Aroma intensity & $2.27^{\mathrm{a}}$ & $2.53^{\mathrm{a}}$ & $2.54^{\mathrm{a}}$ & $\mathrm{NS}^{3}$ & $*$ & 0.469 \\
\hline Cooked & $3.69^{\mathrm{a}}$ & $3.67^{\mathrm{a}}$ & $3.62^{\mathrm{a}}$ & 0.09 & $*$ & 0.779 \\
\hline Dairy sour & $1.67^{\mathrm{a}}$ & $1.69^{\mathrm{a}}$ & $1.75^{\mathrm{a}}$ & 0.10 & * & 0.612 \\
\hline Beefy/brothy & $\mathrm{ND}^{4}$ & $0.48^{\mathrm{a}}$ & $0.54^{\mathrm{a}}$ & 0.31 & $*$ & 0.679 \\
\hline Cardboard & ND & $1.05^{\mathrm{ab}}$ & $1.70^{\mathrm{a}}$ & 1.51 & * & 0.896 \\
\hline Soapy & ND & $0.85^{\mathrm{ab}}$ & $1.20^{\mathrm{a}}$ & 0.99 & $*$ & 0.789 \\
\hline Acetaldehyde & $2.21^{\mathrm{a}}$ & $1.41^{\mathrm{a}}$ & $2.29^{\mathrm{a}}$ & 1.03 & $*$ & 0.752 \\
\hline Sweet taste & $1.38^{\mathrm{a}}$ & $1.41^{\mathrm{a}}$ & $1.35^{\mathrm{a}}$ & NS & * & 0.557 \\
\hline Sour taste & $2.39^{\mathrm{a}}$ & $2.40^{\mathrm{a}}$ & $2.68^{\mathrm{a}}$ & 0.33 & * & 0.700 \\
\hline Umami taste & ND & 1.38 & ND & NS & * & 0.901 \\
\hline Astringency & $2.75^{\mathrm{a}}$ & $2.86^{\mathrm{a}}$ & $2.84^{\mathrm{a}}$ & 0.12 & * & 0.599 \\
\hline Aftertaste & $1.08^{\mathrm{b}}$ & $1.23^{\mathrm{ab}}$ & $1.41^{\mathrm{a}}$ & 0.31 & $*$ & 0.546 \\
\hline \multicolumn{7}{|c|}{$\overline{\mathrm{a}, \mathrm{b}}$ Within a row, different superscripts indicate a significant difference among protein sources $(P<0.05)$. } \\
\hline \multicolumn{7}{|c|}{${ }^{1}$ Attributes were scored on a 0- to 15-point universal intensity scale (Meilgaard et al., 2007; Desai et al., 2013) } \\
\hline \multirow{2}{*}{\multicolumn{7}{|c|}{$\begin{array}{l}{ }^{2} \mathrm{SMC}=\text { skim milk concentrate yogurt; AWP = acid whey protein yogurt; SWP = sweet whey protein yogurt } \\
\text { Values are LSM. }\end{array}$}} \\
\hline & & & & & & \\
\hline \multirow{2}{*}{\multicolumn{7}{|c|}{$\begin{array}{l}{ }^{3} \mathrm{NS}=\text { the term for protein source in the ANOVA model was not significant }(P>0.05) \text {; therefore, calculation } \\
\text { and use of LSD is not valid. }\end{array}$}} \\
\hline & & & & & & \\
\hline$* P<0.05$ & & & & & & \\
\hline
\end{tabular}


ACID WHEY PROTEIN

Table 6. Trained panel texture profiles of nonfat yogurts evaluated at $1,14,28$, and $56 \mathrm{~d}$ of storage at $4^{\circ} \mathrm{C}^{1}$

\begin{tabular}{|c|c|c|c|c|c|c|}
\hline \multirow[b]{2}{*}{ Attribute } & \multicolumn{3}{|c|}{ Protein source ${ }^{2}$} & \multirow[b]{2}{*}{ LSD } & \multirow{2}{*}{$\begin{array}{l}\text { Time of } \\
\text { storage }\end{array}$} & \multirow[b]{2}{*}{$\mathrm{R}^{2}$} \\
\hline & $\mathrm{SMC}$ & AWP & SWP & & & \\
\hline Surface shine & $14.5^{\mathrm{a}}$ & $13.8^{\mathrm{a}}$ & $14.3^{\mathrm{a}}$ & 0.848 & & 0.388 \\
\hline Surface grain & $0.7^{\mathrm{b}}$ & $3.8^{\mathrm{a}}$ & $0.8^{\mathrm{b}}$ & 2.76 & * & 0.863 \\
\hline Spoon indent & $14.5^{\mathrm{ab}}$ & $12.3^{\mathrm{b}}$ & $14.7^{\mathrm{a}}$ & 2.40 & & 0.600 \\
\hline Viscosity & $9.6^{\mathrm{a}}$ & $7.7^{\mathrm{a}}$ & $9.7^{\mathrm{a}}$ & 2.72 & * & 0.666 \\
\hline Firmness & $3.4^{\mathrm{a}}$ & $2.2^{\mathrm{b}}$ & $3.3^{\mathrm{ab}}$ & 1.15 & $*$ & 0.736 \\
\hline Denseness & $6.8^{\mathrm{a}}$ & $6.1^{\mathrm{a}}$ & $6.9^{\mathrm{a}}$ & 0.83 & * & 0.659 \\
\hline Cohesiveness & $3.1^{\mathrm{a}}$ & $2.5^{\mathrm{a}}$ & $3.0^{\mathrm{a}}$ & 0.74 & $*$ & 0.537 \\
\hline Graininess & $4.5^{\mathrm{ab}}$ & $5.6^{\mathrm{a}}$ & $4.3^{\mathrm{b}}$ & 1.25 & * & 0.627 \\
\hline Meltaway & $8.4^{\mathrm{a}}$ & $9.5^{\mathrm{a}}$ & $8.5^{\mathrm{a}}$ & 1.33 & * & 0.531 \\
\hline Mouth coating & $6.7^{\mathrm{a}}$ & $7.0^{\mathrm{a}}$ & $7.0^{\mathrm{a}}$ & $\mathrm{NS}^{3}$ & & 0.335 \\
\hline Spoon ropy & 0.6 & $\mathrm{ND}^{4}$ & ND & NS & & 0.643 \\
\hline Jiggle & $3.6^{\mathrm{b}}$ & $5.7^{\mathrm{a}}$ & $4.4^{\mathrm{ab}}$ & 2.06 & $*$ & 0.696 \\
\hline No stir firmness & $4.2^{\mathrm{b}}$ & $2.4^{\mathrm{b}}$ & $4.4^{\mathrm{ab}}$ & 1.95 & * & 0.457 \\
\hline No stir denseness & $7.1^{\mathrm{a}}$ & $5.9^{\mathrm{a}}$ & $7.1^{\mathrm{a}}$ & 1.81 & * & 0.767 \\
\hline Ropy & ND & 1.2 & ND & NS & & 0.783 \\
\hline Slurp viscosity & $12.3^{\mathrm{a}}$ & $9.7^{\mathrm{b}}$ & $11.5^{\mathrm{ab}}$ & 2.60 & * & 0.746 \\
\hline
\end{tabular}

$\overline{\mathrm{a}, \mathrm{b}}$ Within a row, different superscripts indicate a significant difference among protein sources $(P<0.05)$.

${ }^{1}$ Attributes were scored on a 0- to 15 -point product-specific intensity scale (Meilgaard et al., 2007; Desai et al., 2013).

${ }^{2} \mathrm{SMC}=$ skim milk concentrate yogurt; AWP = acid whey protein yogurt; SWP $=$ sweet whey protein yogurt. Values are LSM.

${ }^{3} \mathrm{NS}=$ the term in the ANOVA model was not significant $(P>0.05)$; therefore, calculation and use of LSD is not valid.

${ }^{4}$ Not detected.

$* P<0.05$.

(68.5\%). The majority of consumers reported consuming yogurt at least once a week $(73.3 \%)$.

The SMC yogurts had higher overall liking scores than AWP yogurts in all categories $(P<0.05$; Table 7$)$. On the basis of appearance, consumers preferred SMC yogurt $(P<0.05)$, and AWP and SWP yogurts were at parity $(P>0.05)$. Flavor liking was significantly higher for SWP and SMC yogurts than for AWP yogurt $(P<0.05)$. Consumers indicated that they liked the tartness and sweetness of the SMC and SWP yogurts more than the AWP yogurt $(P<0.05)$. Thickness and texture liking scores were significantly lower in AWP than in SMC and SWP $(P<0.05)$. Both SWP and AWP yogurts had significant penalties in overall liking for having "too little" thickness and "too little" texture $(P<0.05$; results not shown). These results in conjunction with trained panel texture results suggested that texture was the primary reason for the lower overall liking score of AWP yogurt compared with SMC yogurt.

\section{Yogurt Reformulation for a Second Consumer Trial}

The objective of the second consumer trial was to develop a yogurt that used whey protein from acid whey and was acceptable to consumers. Upon completion of the initial consumer test, reformulation of the AWP yogurts was necessary to increase consumer liking scores. Consumer scores indicated that texture was the primary reason yogurts were not liked. Trained panel (Table 6) and instrumental data (Figures 4 and 5) were consistent with consumer panel scores (Table 7 ) in that the texture of AWP yogurts was the most distinct attribute compared with SMC or SWP yogurts. All yogurts were reformulated with increased total fat (0.2 to $2.0 \%$ ), decreased total protein (6.0 to $5.0 \%$ ), and increased

Table 7. Consumer $(\mathrm{n}=100)$ liking scores $^{1}$ (SE in parentheses) for nonfat yogurts mixed with strawberry fruit prep base at 20\% (wt/wt)

\begin{tabular}{lccc}
\hline & \multicolumn{3}{c}{ Protein source $^{2}$} \\
\cline { 2 - 4 } Attribute & SMC & AWP & SWP \\
\hline Overall & $7.0^{\mathrm{a}}(0.075)$ & $5.0^{\mathrm{c}}(0.122)$ & $6.0^{\mathrm{b}}(0.108)$ \\
Appearance & $6.8^{\mathrm{a}}(0.070)$ & $6.0^{\mathrm{b}}(0.081)$ & $6.0^{\mathrm{b}}(0.102)$ \\
Flavor & $6.9^{\mathrm{a}}(0.080)$ & $5.6^{\mathrm{c}}(0.109)$ & $6.4^{\mathrm{b}}(0.090)$ \\
Tartness & $6.6^{\mathrm{a}}(0.079)$ & $5.6^{\mathrm{b}}(0.098)$ & $6.3^{\mathrm{a}}(0.089)$ \\
Sweetness & $6.6^{\mathrm{a}}(0.087)$ & $5.7^{\mathrm{b}}(0.105)$ & $6.5^{\mathrm{a}}(0.085)$ \\
Thickness & $6.9^{\mathrm{a}}(0.085)$ & $4.6^{\mathrm{c}}(0.106)$ & $5.9^{\mathrm{b}}(0.112)$ \\
Texture & $6.7^{\mathrm{a}}(0.089)$ & $4.2^{\mathrm{c}}(0.118)$ & $5.3^{\mathrm{b}}(0.122)$ \\
Aftertaste & $6.0^{\mathrm{a}}(0.089)$ & $4.9^{\mathrm{b}}(0.096)$ & $5.9^{\mathrm{a}}(0.078)$ \\
\hline
\end{tabular}

${ }^{\mathrm{a}-\mathrm{c}}$ Within a row, different superscripts indicate a significant difference within a day $(P<0.05)$.

${ }^{1}$ Liking was scored on a 9 -point hedonic scale $(1=$ dislike extremely, $9=$ like extremely).

${ }^{2} \mathrm{SMC}=$ skim milk concentrate yogurt; AWP $=$ acid whey protein yogurt; SWP = sweet whey protein yogurt. 
sugar (6.5 to $8.0 \%$ ). Janiaski et al. (2016) documented that increasing fat content in yogurts improved the sensory texture attributes viscosity and smoothness. Modified food starch (Ingredion, Westchester, IL) was also added to all yogurts at 1.0\% (wt/wt). Modified food starch has been documented to increase thickness of yogurt (Schmidt et al., 2000; Nguyen et al., 2017). The AWP yogurt also had added gelatin $(0.20 \%$ wt/ wt; Geliko, New York, NY) to increase thickness and gellan gum (0.02\% wt/wt; Tic Gums, Bellcamp, MD) to reduce graininess (Fiszman et al., 1999). Gelatin reduces syneresis and improves sensory perception of yogurt texture (Nguyen et al., 2017; Pang et al., 2017).

Reformulated yogurt mixes were processed and fermented in duplicate as previously described for nonfat yogurts in the current study. The composition of the reformulated yogurt mixes is given in Table 2. During manufacture, the fermentation time to achieve a $\mathrm{pH}$ of 4.7 before cooling was about 50 min longer for reformulated $2 \%$ fat AWP and SWP yogurts than for the SMC yogurt as reported for the fat-free yogurts (Figure 1). The $\mathrm{pH}$ and TA of the reformulated AWP, SWP, and SMC $2 \%$ yogurts did not differ $(P>0.05)$ after $14 \mathrm{~d}$ of storage and were 4.49, 4.45, and 4.43 and 1.01, 0.92 , and $0.98 \%$ expressed as lactic acid, respectively. Yogurts were stored for $14 \mathrm{~d}$, and trained panel profiling and consumer acceptance testing were conducted as previously described. Yogurts for consumer testing were mixed with a strawberry fruit base at $20 \%$ (wt/ wt). The fruit base was blended into yogurt by hand on d 14 before consumer testing.

Descriptive analysis results of reformulated yogurt white mass showed expected changes in AWP yogurt for flavor (Table 8) and texture (Table 9) attributes such that the flavor and texture profiles were more similar to those of SMC yogurts. Milkfat flavor was documented, and sweet taste was higher in the reformulated yogurts compared with the initial formulations, which was expected due to the added sugar and increase in fat content. Cardboard and soapy notes were no longer detected in the reformulated AWP yogurt, also consistent with previous work with fat-free versus fat-containing yogurts (Desai et al., 2013). Firmness and viscosity were increased in the reformulated AWP yogurt $(P$ $<0.05)$ compared with SWP and SMC reformulated yogurts, and ropy and spoon ropy attributes were no longer detected (Table 9). Consumer liking scores for reformulated yogurts are shown in Table 10. Consumer demographics were similar to those in the previous consumer test. The AWP yogurt was favored or at parity with SMC and SWP yogurts. The use rate of both AWP and SWP concentrate ingredient in the reformulated $2 \%$ yogurt was about $30 \%$ of that in the fat-free yogurts (Table 2; see lower contribution of whey protein
Table 8. Trained panel flavor profiles (SE in parentheses) of reformulated $2 \%$ fat yogurts on d $14^{1}$

\begin{tabular}{lccc}
\hline & \multicolumn{3}{c}{ Protein source $^{2}$} \\
\cline { 2 - 4 } Flavor attribute & SMC & AWP & SWP \\
\hline Aroma intensity & $2.4^{\mathrm{a}}(0.060)$ & $1.8^{\mathrm{b}}(0.099)$ & $1.8^{\mathrm{b}}(0.084)$ \\
Cooked & $4.0^{\mathrm{b}}(0.017)$ & $3.9^{\mathrm{b}}(0.030)$ & $4.1^{\mathrm{a}}(0.063)$ \\
Dairy sour & $2.0^{\mathrm{a}}(0.032)$ & $1.6^{\mathrm{c}}(0.037)$ & $1.7^{\mathrm{b}}(0.039)$ \\
Milkfat & $1.0^{\mathrm{b}}(0.104)$ & $1.4^{\mathrm{a}}(0.067)$ & $1.2^{\mathrm{b}}(0.064)$ \\
Cardboard & $\mathrm{ND}^{3}$ & $\mathrm{ND}$ & $0.9^{\mathrm{a}}(0.063)$ \\
Beefy/brothy & $\mathrm{ND}$ & $\mathrm{ND}$ & $\mathrm{ND}$ \\
Soapy & $\mathrm{ND}$ & $\mathrm{ND}$ & $\mathrm{ND}$ \\
Acetaldehyde & $2.7^{\mathrm{a}}(0.067)$ & $1.9^{\mathrm{b}}(0.050)$ & $1.7^{\mathrm{c}}(0.070)$ \\
Sweet taste & $5.4^{\mathrm{a}}(0.066)$ & $5.5^{\mathrm{a}}(0.066)$ & $4.7^{\mathrm{b}}(0.113)$ \\
Sour taste & $2.0^{\mathrm{c}}(0.031)$ & $2.3^{\mathrm{b}}(0.050)$ & $2.6^{\mathrm{a}}(0.043)$ \\
Aftertaste intensity & $1.1^{\mathrm{a}}(0.079)$ & $1.0^{\mathrm{a}}(0.067)$ & $1.0^{\mathrm{a}}(0.059)$ \\
Umami taste & $\mathrm{ND}$ & $0.7^{\mathrm{a}}(0.061)$ & $\mathrm{ND}$ \\
Astringency & $2.7^{\mathrm{b}}(0.044)$ & $2.9^{\mathrm{a}}(0.075)$ & $2.8^{\mathrm{ab}}(0.082)$ \\
\hline
\end{tabular}

${ }^{a-c}$ Within a row, different superscripts indicate a significant difference within a day $(P<0.05)$.

${ }^{1}$ Attributes were scored on a 0 - to 15 -point product-specific scale (Meilgaard et al., 2007).

${ }^{2} \mathrm{SMC}=$ skim milk concentrate yogurt; AWP $=$ acid whey protein yogurt; SWP = sweet whey protein yogurt.

${ }^{3}$ Not detected.

from AWP and SWP concentrates). This reduction in use rate probably was the main reason why consumer scores were similar for all 3 yogurt treatments for the $2 \%$ fat reformulated yogurts.

In this experiment, about $460 \mathrm{~kg}$ of neutralized acid whey was concentrated to about $10 \mathrm{~kg}$ of AWP WPC 80 ingredient (27.1\% TS, $19.5 \%$ true protein). A typical cottage cheese plant with 10 cheese vats uses approximately $140,000 \mathrm{~kg}$ of skim milk daily to produce cottage

Table 9. Trained panel texture profiles (SE in parentheses) of reformulated $2 \%$ fat yogurts on d $14^{1}$

\begin{tabular}{|c|c|c|c|}
\hline \multirow[b]{2}{*}{ Texture attribute } & \multicolumn{3}{|c|}{ Protein source $^{2}$} \\
\hline & $\mathrm{SMC}$ & AWP & SWP \\
\hline Surface shine & $10.5^{\mathrm{a}}(0.081)$ & $9.9^{\mathrm{b}}(0.114)$ & $10.4^{\mathrm{a}}(0.128)$ \\
\hline Surface grain & $3.4^{\mathrm{b}}(0.097)$ & $5.7^{\mathrm{a}}(0.138)$ & $3.8^{\mathrm{ab}}(0.180)$ \\
\hline Spoon indent & $10.2^{\mathrm{a}}(0.311)$ & $11.2^{\mathrm{a}}(0.144)$ & $10.2^{\mathrm{a}}(0.237)$ \\
\hline Viscosity & $8.4^{\mathrm{b}}(0.101)$ & $9.1^{\mathrm{a}}(0.125)$ & $8.4^{\mathrm{b}}(0.160)$ \\
\hline Firmness & $2.4^{\mathrm{b}}(0.073)$ & $2.9^{\mathrm{a}}(0.093)$ & $2.5^{\mathrm{b}}(0.079)$ \\
\hline Denseness & $6.5^{\mathrm{b}}(0.097)$ & $7.1^{\mathrm{a}}(0.090)$ & $6.6^{\mathrm{b}}(0.180)$ \\
\hline Cohesiveness & $2.2^{\mathrm{b}}(0.059)$ & $2.6^{\mathrm{a}}(0.089)$ & $2.4^{\mathrm{b}}(0.110)$ \\
\hline Graininess & $3.0^{\mathrm{a}}(0.089)$ & $2.4^{\mathrm{b}}(0.084)$ & $2.7^{\mathrm{b}}(0.115)$ \\
\hline Meltaway & $11.1^{\mathrm{a}}(0.081)$ & $10.9^{\mathrm{a}}(0.141)$ & $11.1^{\mathrm{a}}(0.129)$ \\
\hline Mouth coating & $6.6^{\mathrm{b}}(0.143)$ & $7.1^{\mathrm{a}}(0.170)$ & $7.0^{\mathrm{ab}}(0.125)$ \\
\hline
\end{tabular}

$\overline{a, b}$ Within a row, different superscripts indicate a significant difference within a day $(P<0.05)$.

${ }^{1}$ Attributes were scored on a 0 - to- 15 point product-specific intensity scale (Meilgaard et al., 2007). The attributes ropy and spoon ropy were not detected in reformulated yogurts. The attributes jiggle, no stir firmness, denseness, and slurp viscosity were not evaluated in reformulated yogurts.

${ }^{2} \mathrm{SMC}=$ skim milk concentrate yogurt; AWP $=$ acid whey protein yogurt; SWP = sweet whey protein yogurt. 
Table 10. Consumer $(n=100)$ liking scores ${ }^{1}(\mathrm{SE}$ in parentheses) for $2 \%$ fat reformulated yogurts mixed with strawberry fruit prep base at $20 \%$ (wt/wt)

\begin{tabular}{lccc}
\hline & \multicolumn{3}{c}{ Protein source $^{2}$} \\
\cline { 2 - 4 } Attribute & SMC & AWP & SWP \\
\hline Overall & $6.9^{\mathrm{a}}(0.141)$ & $7.2^{\mathrm{a}}(0.131)$ & $7.2^{\mathrm{a}}(0.126)$ \\
Appearance & $6.9^{\mathrm{b}}(0.140)$ & $7.3^{\mathrm{a}}(0.076)$ & $7.3^{\mathrm{a}}(0.115)$ \\
Flavor & $7.0^{\mathrm{a}}(0.131)$ & $7.2^{\mathrm{a}}(0.131)$ & $7.2^{\mathrm{a}}(0.124)$ \\
Tartness & $6.8^{\mathrm{a}}(0.139)$ & $6.8^{\mathrm{a}}(0.153)$ & $6.9^{\mathrm{a}}(0.127)$ \\
Sweetness & $6.7^{\mathrm{a}}(0.154)$ & $6.9^{\mathrm{a}}(0.161)$ & $6.8^{\mathrm{a}}(0.165)$ \\
Thickness & $6.9^{\mathrm{b}}(0.148)$ & $7.3^{\mathrm{a}}(0.117)$ & $7.1^{\mathrm{ab}}(0.133)$ \\
Texture & $6.6^{\mathrm{b}}(0.177)$ & $7.4^{\mathrm{a}}(0.120)$ & $7.0^{\mathrm{a}}(0.130)$ \\
Aftertaste & $6.0^{\mathrm{a}}(0.142)$ & $6.7^{\mathrm{a}}(0.157)$ & $6.2^{\mathrm{a}}(0.170)$ \\
\hline
\end{tabular}

${ }^{\mathrm{a}, \mathrm{b}}$ Within a row, different superscripts indicate a significant difference within a day $(P<0.05)$.

${ }^{1}$ Liking was scored on a 9 -point hedonic scale $(1=$ dislike extremely, $9=$ like extremely).

${ }^{2} \mathrm{SMC}=$ skim milk concentrate yogurt; AWP $=$ acid whey protein yogurt; SWP = sweet whey protein yogurt.

cheese (C. Podgurski, Upstate Milk Cooperative Inc., Buffalo, NY, personal communication) with $14.3 \%$ curd yield. This equates to about $120,000 \mathrm{~kg}$ of acid whey daily as a result of cottage cheese production. Using the neutralization and concentration techniques outlined in this paper, a cottage cheese producer with similar milk usage as mentioned above could produce approximately $5,280 \mathrm{~kg}$ of concentrated neutralized acid whey WPC 80 ingredient for use in yogurt production. The reformulated yogurts used the neutralized acid whey WPC 80 ingredient at 2.5\%. With this formulation, enough AWP WPC 80 ingredient could be made daily to supplement the production of about $207,000 \mathrm{~kg}$ of yogurt. According to the USDA (2017) dairy products summary, NDM was sold at $\$ 2.38 / \mathrm{kg}$. Replacing NDM with the neutralized AWP WPC 80 ingredient could save up to about $\$ 12,500 /$ d. Liquid AWP WPC 80 might also be used as a partial replacement for NDM in cottage cheese dressing in the same factory.

\section{CONCLUSIONS}

Fat-free yogurt produced with added neutralized fresh liquid acid WPC had flavor attributes similar to those of fat-free yogurts with added fresh liquid SWP ingredient but had lower gel strength attributes, which translated to differences in trained panel texture attributes and lower consumer liking scores for yogurt made with added AWP ingredient. Difference in $\mathrm{pH}$ was the main contributor to texture differences, as higher $\mathrm{pH}$ in AWP yogurts changed gel structure formation and water-holding capacity of the yogurt gel. Reformulation to address texture differences resulted in $2 \%$ milkfat yogurts using the AWP ingredient that performed at parity with control yogurts in consumer sensory trials.
Fresh liquid acid WPC from cottage cheese manufacture can be used as a liquid protein ingredient source for yogurt manufacture in the same factory.

\section{ACKNOWLEDGMENTS}

Funding was provided in part by the New York State Milk Promotion Board and the National Dairy Council (Rosemont, IL). Use of names, names of ingredients, and specific models of equipment is for scientific clarity and does not constitute any endorsement of product by the authors, Cornell University, North Carolina State University, or the Northeast or Southeast Dairy Foods Research Centers.

\section{REFERENCES}

Aguilera, J. M., and H. G. Kessler. 1989. Properties of mixed and filled-type dairy gels. J. Food Sci. 54:1213-1217.

AOAC International. 2016. Official Methods of Analysis. 20th ed. AOAC Int., Gaithersburg, MD.

Bals, A., and U. Kulozik. 2003. Effect of preheating on the foaming properties of whey protein isolate using a membrane foaming apparatus. Int. Dairy J. 13:903-908.

Barrantes, L. D., and C. V. Morr. 1997. Partial deacidification and demineralization of cottage cheese whey by nanofiltration. J. Food Sci. 62:338-341.

Carunchia Whetstine, M. E., K. R. Cadwallader, and M. A. Drake. 2005. Characterization of aroma compounds responsible for rosy/ floral flavor in Cheddar cheese. J. Agric. Food Chem. 53:31263132 .

Chandrapala, J., M. C. Duke, S. R. Gray, B. Zisu, M. Weeks, M. Palmer, and T. Vasiljevic. 2015. Properties of acid whey as a function of $\mathrm{pH}$ and temperature. J. Dairy Sci. 98:4352-4363.

Cheng, N., D. M. Barbano, and M. A. Drake. 2018. Hunter verses CIE color measurement systems for analysis of milk-based beverages. J. Dairy Sci. 101:4891-4905.

de Wit, J. N. 1998. Nutritional and functional characteristics of whey proteins in food products. J. Dairy Sci. 81:597-608.

Dec, B., and W. Chojnowski. 2006. Characteristics of acid whey powder partially demineralised by nanofiltration. Pol. J. Food Nutr. Sci. 15:87-90.

Desai, N. T., L. Shepard, and M. A. Drake. 2013. Sensory properties and drivers of liking for Greek yogurts. J. Dairy Sci. 96:7454-7466.

Drake, S. L., M. E. Carunchia Whetstine, M. A. Drake, P. Courtney, K. Fligner, J. Jenkins, and C. Pruitt. 2007. Sources of umami taste in Cheddar and Swiss cheeses. J. Food Sci. 72:S360-S366.

Erickson, B. E. 2017. Acid whey: Is the waste product an untapped goldmine? Accessed Feb. 6, 2017. http://cen.acs.org/articles/95/ i6/Acid-whey-waste-product-untapped.html.

Fiszman, S. M., M. A. Lluch, and A. Salvador. 1999. Effect of addition of gelatin on microstructure of acidic milk gels and yoghurt and on their rheological properties. Int. Dairy J. 9:895-901.

Glantz, S. A., and B. K. Slinker. 2001. Multicollinearity and what to do about it. Pages 185-187 in Primer of Applied Regression and Analysis of Variance. 2nd ed. McGraw-Hill, New York, NY.

Harwalker, V. R., and M. Kalab. 1983. Susceptibility of yogurt to syneresis. Comparison of centrifugation and drainage methods. Milchwissenschaft 38:517-522.

Hooi, R., D. M. Barbano, R. L. Bradley, D. Budde, M. Bulthaus, M. Chettiar, J. Lynch, and R. Reddy. 2004a. Acidity, titratable-Phenolphthalein indicator. Pages 427-434 in Standard Methods for the Examination of Dairy Products. Vol. 17. H. M. Wehr and J. F. Frank, ed. American Public Health Association, Washington, DC.

Hooi, R., D. M. Barbano, R. L. Bradley, D. Budde, M. Bulthaus, M. Chettiar, J. Lynch, and R. Reddy. 2004b. Mojonnier method, milk 
and cream; Other products. Pages 364-366 in Standard Methods for the Examination of Dairy Products. Vol. 17. H. M. Wehr and J. F. Frank, ed. American Public Health Association, Washington, DC.

Houzé, G., E. Cases, B. Colas, and P. Cayot. 2005. Viscoelastic properties of acid milk gel as affected by fat nature at low level. Int. Dairy J. 15:1006-1016.

IDFA (International Dairy Foods Association). 2017. Cultured products. Accessed May 17, 2017. https://www.idfa.org/resource -center/industry-facts/cultured-products.

Janiaski, D. R., T. C. Pimentel, A. G. Cruz, and H. Prudencio. 2016 Strawberry-flavored yogurts and whey beverages: What is the sensory profile of the ideal product? J. Dairy Sci. 99:5273-5283.

Kersten, S., B. S. Murray, and E. Dickinson. 2005. Confocal microscopy of heat-induced aggregation and gelation of $\beta$-lactoglobulin in presence of non-ionic surfactant. Food Hydrocolloids 19:625-633.

Kilara, A., and R. C. Chandan. 2013. Greek-style yogurt and related products. Pages 297-318 in Manufacturing Yogurt and Fermented Milks. Vol. 1. R. C. Chandan and A. Kilara, ed. Wiley-Blackwell, West Sussex, UK.

Kontopidis, G., C. Holt, and L. Sawyer. 2002. The ligand-binding site of bovine $\beta$-lactoglobulin: Evidence for a function? J. Mol. Biol. 318:1043-1055.

Kontopidis, G., C. Holt, and L. Sawyer. 2004. Invited review: $\beta$-Lactoglobulin: Binding properties, structure, and function. J. Dairy Sci. 87:785-796.

Leksrisompong, P. P., R. E. Miracle, and M. A. Drake. 2010. Characterization of flavor of whey protein hydrolysates. J. Agric. Food Chem. 58:6318-6327.

Leman, J., T. Dolgan, M. Smoczynski, and Z. Dziuba. 2005. Fractal characteristics of microstructure of beta-lactoglobulin preparations and their emulsifying properties. Electronic J. Polish Agric. Univ. $8: 29$.

Lopes, G. K., D. S. Alviano, D. Torres, M. P. Goncalves, and C. T. Andrade. 2006. Gelation of whey protein concentrate in the presence of partially hydrolyzed waxy maize starch and urea at $\mathrm{pH} 7.5$. Colloid Polymer Sci. 285:203-210.

Lucey, J. A., P. A. Munro, and H. Singh. 1998. Whey separation in acid skim milk gels made with glucono-delta-lactone: Effects of heat treatment and gelation temperature. J. Texture Stud. 29:413426.

Lucey, J. A., P. A. Munro, and H. Singh. 1999. Effects of heat treatment and whey protein addition on the rheological properties and structure of acid skim milk gels. Int. Dairy J. 9:275-279.

Martens, R. 1972. Influence of some factors on the consistency and the taste of stirred yogurt. Rev. Agric. (Piracicaba) 25:461-480.

Martin, N. C., J. Skokanova, E. Latrille, C. Beal, and G. Corrieu. 1999. Influence of fermentation and storage conditions on the sensory properties of plain lowfat stirred yogurts. J. Sens. Stud. 14:139-160.

Meilgaard, M., G. V. Civille, and B. T. Carr. 2007. Descriptive analysis techniques. Pages 173-188 in Sensory Evaluation Techniques. 4th ed. CRC Press, Boca Raton, FL.

Modler, H. W., M. E. Larmond, C. S. Lin, D. Froehlich, and D. B. Emmons. 1983. Physical and sensory properties of yogurt stabilized with milk proteins. J. Dairy Sci. 66:422-429.

Morr, C. V., and E. Y. W. Ha. 1993. Whey protein concentrates and isolates: Processing and functional properties. Crit. Rev. Food Sci. Nutr. 33:431-476.

Nguyen, P. T. M., O. Kravchuk, B. Bhandari, and S. Prakash. 2017. Effect of different hydrocolloids on texture, rheology, tribology and sensory perception of texture and mouthfeel of low-fat pot-set yoghurt. Food Hydrocolloids 72:90-104.

Oltman, A. E., K. Lopetcharat, E. Bastian, and M. A. Drake. 2015. Identifying key attributes for protein beverages. J. Food Sci. 80:S1383-S1390.

Onwulata, C. I., P. W. Smith, R. P. Konstance, and V. H. Holsinger. 2001. Incorporation of whey products in extruded corn, potato or rice snacks. Food Res. Int. 34:679-687.

Pang, Z., H. Deeth, H. Yang, S. Prakash, and N. Bansal. 2017. Evaluation of tilapia skin gelatin as a mammalian gelatin replacer in acid milk gels and low-fat stirred yogurt. J. Dairy Sci. 100:3436-3447.

Prazeres, A. R., F. Carvalho, and J. Rivas. 2012. Cheese whey management: A review. J. Environ. Manage. 110:48-68.

Quiñones, H. J., D. M. Barbano, and L. G. Phillips. 1997. Influence of protein standardization by ultrafiltration on the viscosity, color, and sensory properties of skim and $1 \%$ milk. J. Dairy Sci. $80: 3142-3151$

Reineccius, G. 2006. Flavor analysis. Pages 33-72 in Flavor Chemistry and Technology. Vol. 2. Taylor and Francis, Boca Raton, FL.

Rönnegård, E., and P. Dejmek. 1993. Development and breakdown of structure in yoghurt studied by oscillatory rheological measurements. Lait 73:371-379.

Rubico, S. M., and M. R. McDaniel. 1992. Sensory evaluation of acids by free-choice profiling. Chem. Senses 17:273-289.

Schamberger, G. P., and T. P. Labuza. 2006. Evaluation of front-face fluorescence for assessing thermal processing of milk. J. Food Sci 71:C69-C74.

Schmidt, K. A., T. J. Herald, and K. A. Khatib. 2000. Modified wheat starches used as stabilizers in set-style yogurt. J. Food Quality 24:421-434.

Shepard, L., R. E. Miracle, P. Leksrisompong, and M. A. Drake. 2013. Relating sensory and chemical properties of sour cream to consumer acceptance. J. Dairy Sci. 96:5435-5454.

Smith, S., T. J. Smith, and M. A. Drake. 2016. Short communication: Flavor and flavor stability of cheese, rennet, and acid wheys. J. Dairy Sci. 99:3434-3444.

Smithers, G. W. 2015. Whey-ing up the options: Yesterday, today and tomorrow. Int. Dairy J. 48:2-14.

Sodini, I., J. Montella, and P. S. Tong. 2005. Physical properties of yogurt fortified with various commercial whey protein concentrates. J. Sci. Food Agric. 85:853-859.

Tunick, M. H. 2009. Whey protein production and utilization: A brief history. Pages 1-13 in Whey Processing, Functionality and Health Benefits. Vol. 1. C. I. Onwulata and P. J. Huth, ed. Wiley, Ames, IA.

USDA. 2015. Dairy products 2015 summary. Accessed Feb. 6, 2017. http://usda.mannlib.cornell.edu/usda/nass/DairProdSu//2010s/ 2015/DairProdSu-04-29-2015.pdf.

USDA. 2017. Dairy products 2017 summary. Accessed Oct. 2, 2018 http://usda.mannlib.cornell.edu/usda/current/DairProdSu/ DairProdSu-04-26-2018.pdf.

Wagoner, T. B., L. Ward, and E. A. Foegeding. 2015. Using state diagrams for predicting colloidal stability of whey protein beverages. J. Agric. Food Chem. 63:4335-4344.

Whitson, M. E., R. E. Miracle, and M. A. Drake. 2010. Sensory characterization of chemical components responsible for cardboard flavor in whey protein. J. Sens. Stud. 25:616-636.

Yilsay, T. O., L. Yilmaz, and A. A. Bayizit. 2006. The effect of using a whey protein fat replacer on textural and sensory characteristics of low-fat vanilla ice cream. Eur. Food Res. Technol. 222:171-175. 